Abstract-In the coastal waters of the southeastern United States, the blacktip shark (Carcharhinus limbatus) is targeted by recreational anglers and is currently one of the most often captured large coastal shark species. We estimated postrelease mortality (PRM) rates for blacktip sharks captured on rod and reel by shore-based and charter-boat-based fishermen by using acoustic transmitters (number of sharks=81). Additionally, 24 blacktip sharks were tagged with pop-off satellite archival tags (PSATs) to validate the survivorship obtained through analysis of data from the acoustic transmitters. The stress response associated with both recreational capture methods was quantified by using numerous blood chemistry characteristics. Overall, $18.5 \%$ of blacktip sharks died postrelease (17.1\% and $20.0 \%$ of those captured from shore and from charter boats, respectively). The results of survivorship analysis based on data from transmitters are consistent with results inferred from data from PSATs, supporting our use of acoustic transmitters to assess PRM in blacktip sharks. Fight time had a significant effect on blood $\mathrm{pH}$, lactate, hematocrit, potassium, and glucose for sharks caught from shore but only on lactate for sharks caught from charter boats. In general, the blood chemistry characteristics assessed were poor predictors of PRM. Fifty percent of foul-hooked sharks (i.e., sharks hooked anywhere but the jaw) died postrelease, indicating the importance of the effect of hook placement on PRM.

Manuscript submitted 20 February 2020. Manuscript accepted 25 September 2020. Fish. Bull. 118:297-314 (2020).

Online publication date: 9 October 2020. doi: 10.7755/FB.118.3.8

The views and opinions expressed or implied in this article are those of the author (or authors) and do not necessarily reflect the position of the National Marine Fisheries Service, NOAA.

\title{
Stress response and postrelease mortality of blacktip sharks (Carcharhinus limbatus) captured in shore-based and charter-boat-based recreational fisheries
}

\author{
D. Nick Weber (contact author) ${ }^{1,2}$ \\ Bryan S. Frazier ${ }^{1}$ \\ Nicholas M. Whitney ${ }^{3}$ \\ James Gelsleichter ${ }^{4}$ \\ Gorka Sancho ${ }^{2}$
}

Email address for contact author: d.nick.weber@gmail.com

${ }^{1}$ Marine Resources Research Institute

South Carolina Department of Natural Resources

217 Fort Johnson Road

Charleston, South Carolina 29412

Present address of contact author:

153 Tidal Hall

Texas A\&M University-Corpus Christi

6300 Ocean Drive

Corpus Christi, Texas 78412

${ }^{2}$ Grice Marine Laboratory

Department of Biology

College of Charleston

205 Fort Johnson Road

Charleston, South Carolina 29412

In the late $1900 \mathrm{~s}$, shark populations in the western North Atlantic Ocean declined drastically in size (Musick et al., 1993), because of overexploitation and sharks being captured as bycatch in commercial fisheries (Bonfil, 1994; Rose, 1996). In an effort to ensure the sustainability of shark fisheries, a variety of national and international management measures, including mandated release of imperiled species, were introduced (Ellis et al., 2017). These management measures have since been augmented by an increasing emphasis on the catch and release of sharks by recreational anglers (Bartholomew and Bohnsack, 2005; Skomal, 2007), and the release of captured sharks by both commercial and recreational anglers has become a common practice (Press et al., 2016; Ellis et al., 2017). Although

\author{
${ }^{3}$ Anderson Cabot Center for Ocean Life \\ New England Aquarium \\ 1 Central Wharf \\ Boston, Massachusetts 02110 \\ ${ }^{4}$ Department of Biology \\ University of North Florida \\ 1 UNF Drive \\ Jacksonville, Florida 32224
}

catch and release is broadly advocated to minimize effects on fish stocks, postrelease mortality (PRM) may still occur as a result of the physiological stress or physical injury of capture (Bartholomew and Bohnsack, 2005; Cooke and Schramm, 2007). Therefore, there is an increasing interest in understanding the conditions that bring about PRM, as well as in how to minimize PRM rates (Cooke and Cowx, 2004; Gallagher et al., 2014).

Postrelease mortality rates vary widely among shark species (Ellis et al., 2017) and depend on factors such as gear type, duration of capture, respiratory mode (Dapp et al., 2016), and aerobic scope (Priede, 1985; Korsmeyer et al., 1996; Talwar et al., 2017). Traditionally, PRM rates have been assessed by using pop-off satellite archival tags 
(PSATs) (e.g., Heberer et al., 2010; French et al., 2015), but the cost of such tags often precludes the use of large sample sizes (Donaldson et al., 2008), making accurate assessments of PRM for a species difficult. To circumvent this issue, the use of acoustic telemetry to assess PRM has been investigated in recent years (Kneebone et al., 2013; Kilfoil et al., 2017). Results of previous research indicate that acoustic transmitters can be used to assess PRM in the presence of acoustic receiver arrays (Kneebone et al., 2013; Kilfoil et al., 2017). Because the number of acoustic receivers deployed along the eastern coast of the United States continues to grow (Kneebone et al., 2013), the applicability and effectiveness of this method will likely increase. The smaller size of acoustic transmitters, compared with the size of the electronic tags traditionally used to assess PRM (e.g., PSATs), could reduce any potential effects of the tag on a shark's behavior postrelease. Additionally, the lower cost of acoustic transmitters could allow the assessment of larger sample sizes across a wider range of conditions, providing more robust estimates of PRM.

Efforts have been made to link PRM with perturbations in blood chemistry caused by the stress of capture (Whitney et al., 2017). The stress experienced by captured sharks has traditionally been quantified by an assessment of the acidbase status of blood (e.g., Mandelman and Skomal, 2009), based on the notion that stress causes a decrease in blood $\mathrm{pH}$, known as acidemia, due to both metabolic and respiratory acidoses (Skomal, 2007). Additionally, stress-related cellular fluid shifts, which can result in haemoconcentration and disruptions to ionic and osmotic homeostasis (Wood, 1991; Skomal and Mandelman, 2012), have been quantified through changes in plasma electrolyte concentrations (e.g., Marshall et al., 2012; French et al., 2015). Because interspecific differences in responses to capture stress may be linked to the metabolism and physiology of the species in question (Skomal and Mandelman, 2012), analyzing a suite of blood chemistry characteristics may allow for a better understanding of the implications of capture on subsequent mortality events (Skomal, 2007; French et al., 2015). Moreover, when blood chemistry measurements are coupled with estimates of PRM, insights into the causes of physiological stress and mortality, as well as into potential mitigation measures, can be gained (Skomal, 2007; Mandelman and Skomal, 2009).

The blacktip shark (Carcharhinus limbatus) is a relatively large coastal species with a circumglobal distribution in temperate coastal waters (Compagno, 1984; Castro, 2011). In the western North Atlantic Ocean, blacktip sharks migrate seasonally, inhabiting the nearshore waters of Georgia, South Carolina, and North Carolina during the summer months and moving southward to southeastern Florida during the winter months (Castro, 1996; Kajiura and Tellman, 2016). The coastal distribution of blacktip sharks, combined with the seasonal predictability of their center of abundance (Kajiura and Tellman, 2016), makes them easily accessible for both commercial and recreational fisheries. Consequently, the blacktip shark is currently one of the most often landed large coastal shark species (NMFS, 2019). Compared with other large coastal sharks, blacktip sharks have an intermediate life history, defined by the fact that they have a relatively low age at maturity (4-7 years; Killam and Parsons, 1989), reproduce biennially (Castro, 1996), and have an average of 4-6 pups per reproductive cycle (Bigelow and Schroeder, 1948). Collectively, proximity to the coast, intermediate life history characteristics, and exposure to high commercial and recreational fishing pressure make the blacktip shark particularly sensitive to overfishing.

Few studies have investigated the effects of capture on the blacktip shark, but blood chemistry characteristics measured in blacktip sharks caught on drumlines and longlines indicate that the magnitude of the stress response in this species is greater than that in other carcharhinid species (Mandelman and Skomal, 2009; Marshall et al., 2012; Gallagher et al., 2014). Data on acidbase blood chemistry obtained from blacktip sharks caught on longlines indicate that this species may have a strictly respiratory response to capture because the observed acidosis was driven by increases in $\mathrm{pCO}_{2}$ (Mandelman and Skomal, 2009). Consequently, it has been suggested that blacktip sharks could lack the mechanisms (e.g., splenic red blood cell ejection and red blood cell swelling through $\mathrm{Na}^{+}-\mathrm{H}^{+}$exchangers; Nikinmaa, 1992; Brill et al., 2008) responsible for maintaining or increasing oxygen delivery during strenuous activity (Mandelman and Skomal, 2009). Although the results of this research indicate that blacktip sharks may be particularly sensitive to the stress associated with capture, Whitney et al. (2017) found a relatively low rate of $\mathrm{PRM}$ in the recreational fishery for blacktip sharks in the Gulf of Mexico. Additional data are needed on both the physical and physiological effects of recreational rod-and-reel capture on the blacktip shark, and how these effects influence PRM.

Recreational fishing is increasing in popularity worldwide (Arlinghaus and Cooke, 2009; Press et al., 2016). In particular, a specialized method of fishing that targets large coastal sharks from beaches, known as shore-based or land-based shark angling, has been receiving increasing attention in terms of management and conservation in recent years (Ajemian et al., 2016; Shiffman et al., 2017). The Florida Fish and Wildlife Conservation Commission recently formally defined shore-based shark fishing and instituted a mandatory shore-based shark fishing permit in response to perceived issues with handling methods and mortality of captured sharks (Shiffman et al., 2017). Because shore-based anglers typically bring captured sharks onto the beach for hook removal and photographs, sharks caught from the shore may be subject to increased handling stress and increased exposure to air, reducing the shark's ability to breathe $\left(\right.$ Casselman $\left.^{1}\right)$. However, shore-based anglers often fish at night and on deserted beaches, and there are limited data available on their

\footnotetext{
${ }^{1}$ Casselman, S. J. 2005. Catch-and-release angling: a review with guidelines for proper fish handling practices, $26 \mathrm{p}$. Fish Wildl. Branch, Ontario Minist. Nat. Resour., Peterborough, Canada. [Available from website.]
} 
fishing and handling techniques or on the effects on the survival of released sharks.

Given the attention that recreational shore-based shark fishing has been receiving (Ajemian et al., 2016; Shiffman et al.,2017), and an increased emphasis on catch-and-release angling (Bartholomew and Bohnsack, 2005), the determination of gear- and species-specific PRM rates is critical to the effective management of shark species. Through collaboration with recreational anglers, in this study we assessed PRM rates of blacktip sharks captured and released in both the shore-based and charter-boat-based recreational fisheries and quantified the physiological stress response associated with both recreational capture methods.

\section{Materials and methods}

Research was completed under the South Carolina Code of Law Section 50-5-20 ${ }^{2}$ that authorizes the South Carolina Department of Natural Resources to conduct research in state waters. Research was conducted in accordance with the College of Charleston Institutional Animal Care and Use Committee (IACUC) through protocol no. IACUC-2017-007.

\section{Sampling location and design}

Blacktip sharks were caught with rod and reel by recreational anglers from the shore (i.e., beach) and from charter fishing boats. All fishing from charter boats was conducted by the clients who hired the charter boat; therefore, a wide range of angler experience was sampled. Anglers used their personal fishing equipment, which varied in size and strength, and no input was provided by the authors on the fishing equipment (e.g., rod-and-reel type and size or hook type and size) or capture techniques used. Sampling was conducted from May through October 2017 and from February through October 2018, in the coastal waters of South Carolina and Florida, at locations chosen by participating anglers (Fig. 1, A and B). During each angling trip, reel type (i.e., conventional level wind versus spinning), hook type (circle versus J), and sea-surface temperature were recorded.

Once an angler hooked a shark, the fight time, defined as the time from the initial strike until the time the shark was landed and secured by anglers, was recorded to the nearest second. Once secured, the shark went through the sampling procedure in the state that the angler handled it (e.g., sharks caught from charter boats were sampled either on board the boat or in the water, depending on whether or not the charter captain decided to bring the shark on board for photographs or hook removal). All sharks caught by shore-based anglers were brought out of the water and onto the beach. Sharks were then sampled while the recreational anglers completed their routine (which often included hook removal, measurement,

\footnotetext{
${ }^{2}$ Jurisdiction of Department of Natural Resources, S.C. Code $\S 50-5-20$ (2000). [Available from website.]
}

and photographs), to minimize any increase in handling time due to the sampling procedure. Blood was drawn through caudal venipuncture immediately after the shark was secured, a tag was or tags were applied, fork length was measured (in centimeters), and sex was determined. Phlebotomies were performed through caudal venipuncture to ensure that blood sampling was quick, efficient, and minimally invasive (Lawrence et al., 2020).

Once the sampling procedure was complete, anglers were responsible for releasing the shark. The handling time, defined as the time from when the shark was initially secured to the release of the shark, was recorded to the nearest second. Upon release, the condition of the shark was assigned to 1 of 5 categories, ranging from condition 1 (excellent) to condition 5 (moribund), on the basis of the shark's behavior at release (Table 1). If the anglers decided to revive the shark (i.e., hold the shark in the water until they deemed it strong enough for release), the revival time was recorded. Hook status was recorded as removed or retained, and hook location was recorded. The authors provided no input to the anglers regarding hook removal, and some anglers chose to leave hooks that could not be easily removed.

\section{Blood chemistry}

Blood samples (3 mL) were drawn by using 18-gauge, sterilized needles and heparin-rinsed syringes, and samples were immediately injected into $10-\mathrm{mL}$ vacutainers that contained sodium heparin. To avoid compromising accuracy of blood gas analysis after phlebotomy (Whitney et al., 2017), a subsample of whole blood (90 $\mu \mathrm{L})$ was immediately (within $30 \mathrm{~s}$ ) analyzed for $\mathrm{pH}$ and lactate by using an i-STAT ${ }^{3}$ portable blood analyzer (Zoetis Inc., Parsippany-Troy Hills, NJ) with a CG4+ cartridge (Zoetis Inc.). This analyzer has been used in prior field studies on elasmobranch species (e.g., Mandelman and Skomal, 2009; Brooks et al., 2012; Gallagher et al., 2014), and the relative accuracy of measurements of $\mathrm{pH}$ and lactate in ectothermic sharks has been validated (Gallagher et al., 2010; Harter et al., 2015). Measurements of blood $\mathrm{pH}$ were temperature corrected to sea-surface temperatures at the locations of capture by using the following equation:

$$
p H_{\mathrm{TC}}=p H_{\mathrm{M}}-0.011(T-37),
$$

where $p H_{\mathrm{TC}}=$ temperature-corrected $\mathrm{pH}$ values;

$$
p H_{\mathrm{M}}=\text { measured } \mathrm{pH} \text { values; and }
$$$$
T=\text { sea-surface temperatures }
$$

(Mandelman and Skomal, 2009; Gallagher et al., 2010; Brooks et al., 2012; Kneebone et al., 2013; Gallagher et al., 2014; Whitney et al., 2017). All pH values subsequently reported herein were temperature corrected in this manner.

\footnotetext{
${ }^{3}$ Mention of trade names or commercial companies is for identification purposes only and does not imply endorsement by the National Marine Fisheries Service, NOAA.
} 


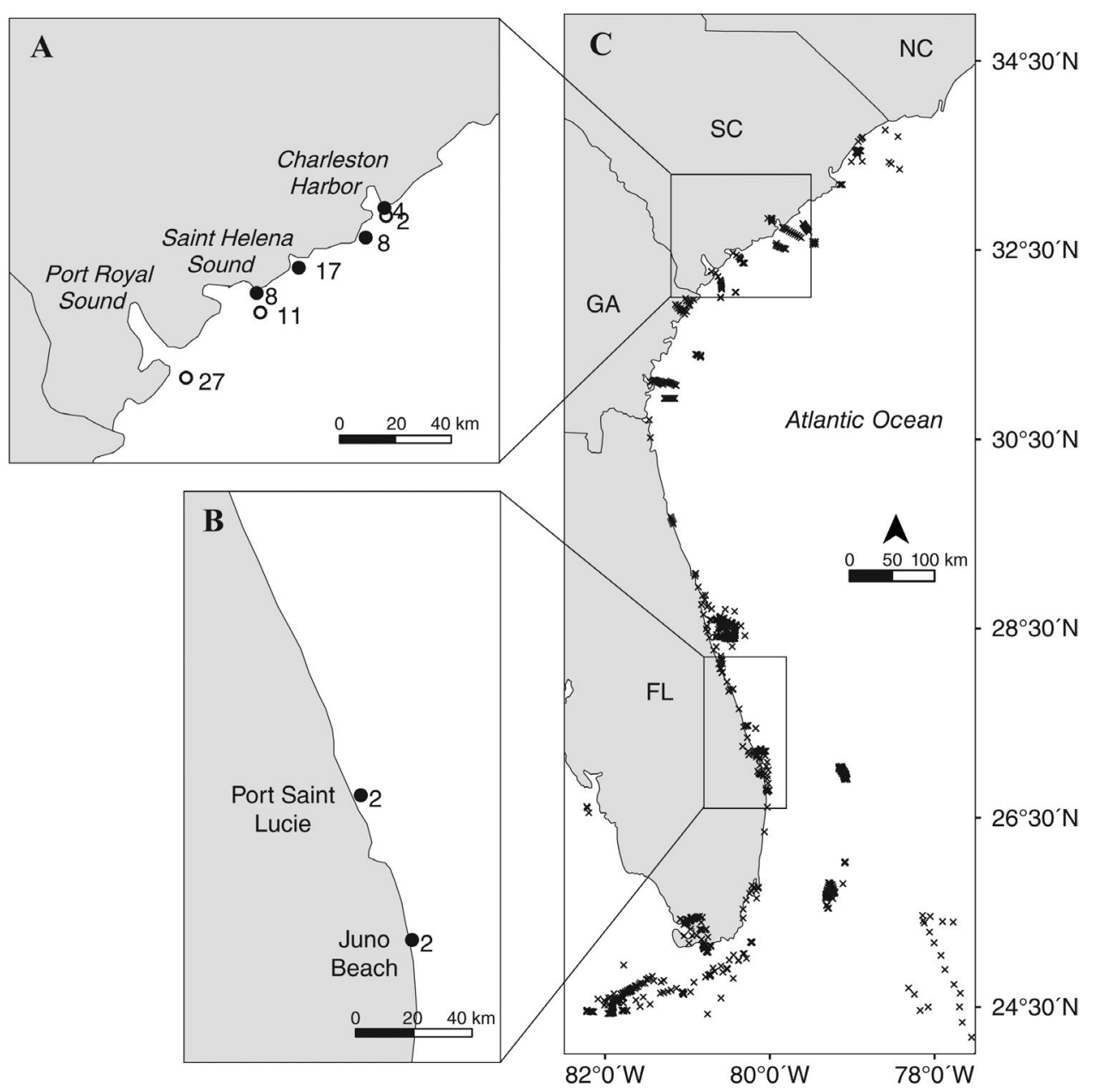

Figure 1

Maps showing the sites where blacktip sharks (Carcharhinus limbatus) were caught and tagged off the coasts of (A) South Carolina and (B) Florida from May through October 2017 and from February through October 2018 and (C) locations of acoustic receivers present along the southeastern coast of the United States. Open circles indicate sites where sharks were caught from charter boats, and solid circles indicate sites where sharks were caught from shore. The numerals next to circles indicate the number of blacktip sharks tagged at each sampling site.

A separate subsample of whole blood $(0.2 \mathrm{~mL})$ was simultaneously placed on ice (within $30 \mathrm{~s}$ ) for hematocrit analysis, which was completed within $4 \mathrm{~h}$ of capture (Manire et al., 2001). At the time of hematocrit analysis, whole blood samples (3 samples per shark) were transferred into microcapillary tubes and centrifuged (centrifuge, Vernitron Medical Products Inc., South Hackensack, NJ) for $5 \mathrm{~min}$ at $10,000 \mathrm{rpm}(10,062 \times$ gravity). Hematocrit was determined as the percentage of total blood volume composed of red blood cells, calculated by using an EZ Reader Microhematocrit Card (LW Scientific Inc., Lawrenceville, GA).

The remaining whole blood was centrifuged (E8 Portafuge, LW Scientific Inc.) for $5 \mathrm{~min}$ at $3500 \mathrm{rpm}(1534 \times$ gravity), to separate the plasma and the red blood cells. Three subsamples of plasma (each $0.5 \mathrm{~mL}$ ) were frozen immediately in liquid nitrogen and, subsequently, stored at $-80^{\circ} \mathrm{C}$. At the time of plasma electrolyte analysis, plasma samples were thawed and diluted with deionized water $\left(\mathrm{dH}_{2} \mathrm{O}\right)$ at a plasma-to- $\mathrm{dH}_{2} \mathrm{O}$ ratio of $2: 3$, and approximately $55 \mu \mathrm{L}$ of the diluted samples was injected into a Critical Care Xpress benchtop analyzer (CCX, Nova Biomedical, Waltham, MA) to quantify levels of $\mathrm{Na}^{+}$, $\mathrm{Cl}^{-}, \mathrm{K}^{+}, \mathrm{Ca}^{2+}, \mathrm{Mg}^{2+}$, and glucose. All concentrations were within the detection limits of the instrument used to measure them.

\section{Postrelease mortality}

Blacktip sharks were tagged with V16-4H acoustic transmitters (Vemco, Bedford, Canada) that measured 18.2 by 


\section{Table 1}

Number of tagged blacktip sharks (Carcharhinus limbatus) assigned to categories of release condition on the basis of behavior at the time of release. Blacktip sharks were caught from shore (number of samples $[n]=41$ ) and from charter boats $(n=40)$, tagged, and then released in coastal waters of South Carolina and Florida between May and October 2017 and between February and October 2018.

\begin{tabular}{clcr}
\hline \multirow{2}{*}{$\begin{array}{c}\text { Condition } \\
\text { category }\end{array}$} & Issues observed and resulting diagnosis & \multicolumn{2}{c}{ Capture method } \\
\cline { 3 - 4 } 1 & Excellent: rapidly swam with no signs of distress & Shore & Charter \\
2 & Good: stressed, swam away but appeared slow or disoriented & 10 & 28 \\
3 & Fair: swam laboriously or had signs of physical trauma & 10 & 10 \\
4 & Poor: attempted to swim and had potentially lethal physical & 7 & 2 \\
5 & trauma (e.g., excessive bleeding or deep hooking) & 0 & 0
\end{tabular}

$88 \mathrm{~mm}$, had a 30 -s nominal delay in transmission rate, and were deployed in an external case. The tagging was accomplished by threading monofilament through a hole drilled into the radial musculature at the base of the first dorsal fin and crimping the monofilament together behind the dorsal fin. This technique of using an external attachment allowed handling times to be short and, therefore, minimized any bias introduced by the tagging procedure (Kilfoil et al., 2017). Survivorship was assessed by passively monitoring sharks following release and examining movements of sharks among fixed acoustic receivers deployed along the southeastern coast of the United States as part of the Atlantic Cooperative Telemetry (ACT) and FACT Networks (Fig. 1C).

To identify and remove false detections potentially created by collisions of acoustic transmitters (Heupel et al., 2006), the full detection database was filtered by using the glatos package (vers. 0.4.2; Holbrook et al., 2020), which flags false detections on the basis of the "short-interval" criteria described by Pincock ${ }^{4}$, in the statistical program R (vers. 3.5.1; R Core Team, 2018). Specifically, detections isolated on a single receiver for more than 30 times the nominal delay of the transmitter (i.e., $15 \mathrm{~min}$ ) were considered to be false and were removed. Because most mortalities associated with a capture event occur within $12 \mathrm{~h}$ of release (Marshall et al., 2015; Talwar et al., 2017; Whitney et al., 2017), sharks that were detected multiple times by an acoustic receiver more than $10 \mathrm{~d}$ postrelease were considered to have survived the capture event. Moreover, because tags that are ingested during predation events are typically regurgitated within approximately $8 \mathrm{~d}$ of ingestion (Kerstetter et al., 2004), we assumed survival only for individuals detected more than $10 \mathrm{~d}$ postrelease to account for possible capture-related predation events

\footnotetext{
${ }^{4}$ Pincock, D. G. 2012. False detections: what they are and how to remove them from detection data. AMIRIX Document DOC-004691, vers. 03, 10 p. [Available from website.]
}

(i.e., acoustic detections recorded $<10 \mathrm{~d}$ postrelease could represent movements of the transmitter consumer rather than the target individual).

To validate the data obtained from the acoustic transmitters and used for survivorship analysis, a subset of sharks were also tagged with PSATs (PSATLife, Lotek Wireless Inc., Newmarket, Canada). The PSATs $(40 \times 125 \mathrm{~mm})$ are designed for monitoring postrelease survival and were programmed to record pressure, external temperature, and light intensity every $10 \mathrm{~s}$ over a 28-d deployment. If the PSAT was not recovered, summary data were obtained from PSATs through the use of satellite-derived pressure-temperature profiles (means for 5-min periods). Recovery of PSATs allowed more detailed analysis of the entire archived data set, which included pressure, external temperature, and light intensity measured every $10 \mathrm{~s}$. The PSATs were programmed to release prematurely if pressure values remained constant $( \pm 50,000 \mathrm{~Pa})$ over a 3 -d period, a consistency in pressure values that would be observed in data from a tag on a dead shark on the ocean floor (Heberer et al., 2010). The PSATs were attached in the same way as the acoustic transmitters, by threading monofilament through a hole drilled into the radial musculature at the base of the first dorsal fin. Survival of sharks tagged with PSATs was inferred by assessing the pressure, external temperature, and light intensity profiles, following protocols previously used to infer mortality from PSAT data records (Heberer et al., 2010).

\section{Data analysis}

Postrelease mortality rates were calculated as the percentage of the total number of tagged individuals that either died after release (as indicated by PSAT data) or were assumed to have died as a result of capture (because they were not detected by an acoustic receiver more than $10 \mathrm{~d}$ after release). For individuals whose PSAT was shed $<10 \mathrm{~d}$ 
postrelease, acoustic telemetry data were used to verify survivorship. We used the Clopper-Pearson interval to calculate $95 \%$ confidence intervals (CIs) for mortality rates. Linear regressions were used to determine if fight time (i.e., time on the line) had an effect on blood chemistry characteristics. Analyses of covariance (ANCOVA) were used to determine if blood chemistry characteristics differed between the 2 recreational capture methods, capture from shore and capture from charter boats, to account for extraneous variability due to differences in fight time between capture methods.

To predict PRM by using the measured blood chemistry characteristics, generalized linear models (GLMs) with a binomial probability distribution and a logit link function were fitted to the data for all sharks combined (number of sharks $[n]=81$ ) and then separately to data for sharks caught from shore $(n=41)$ and to data for sharks caught from charter boats ( $n=40)$ (Schlenker et al., 2016; Talwar et al., 2017). Before constructing the GLMs, principal components analyses were performed to examine potential correlations between explanatory variables and to reduce the number of explanatory variables included in the GLMs (Suppl. Fig. 1). The full models for all sharks combined and for sharks caught from shore described the relationships between PRM as a binary response variable and 4 potential explanatory variables, including $\mathrm{pH}, \mathrm{K}^{+}$, $\mathrm{Na}^{+}$, and glucose. The full model for sharks caught from charter boats included $\mathrm{pH}, \mathrm{K}^{+}$, glucose, and hematocrit as variables. Nonsignificant factors were removed in backward stepwise fashion, starting with the least significant factor and evaluating the increases in deviance and in the Akaike information criterion (AIC) (Akaike, 1973) with each removal (Talwar et al., 2017). The model with the fewest number of explanatory variables and lowest AIC was considered the best-fit model.

To predict PRM with the observed capture characteristics, GLMs were used to describe the relationship between PRM as a binary response variable and water temperature, fight time, handling time, hook location (foul-hooked, i.e., hooked anywhere but the jaw, versus not foul-hooked), release condition, and capture method (from shore versus from charter boat). Because the majority of sharks caught from shore were caught with spinning reels $(76 \%)$ and the majority of sharks caught from charter boats were caught with conventional levelwind reels (85\%), reel type was omitted from the GLM. As previously described, GLMs were fitted to the data for all sharks combined $(n=81)$ and then separately to data for sharks caught from shore $(n=41)$ and to data for sharks caught from charter boats $(n=40)$. The best-fit model was again selected in a backward stepwise fashion and had the fewest number of explanatory variables and lowest AIC.

Fisher's exact tests were used to test the null hypothesis that the distribution of survivors and mortalities was equal across both hook locations and release conditions. All analyses were conducted by using $R$, and all graphs were created in RStudio (vers. 1.1.456; RStudio, Boston, MA). The level of significance for all tests was 0.05 .

\section{Results}

\section{Capture characteristics}

A total of 81 blacktip sharks were caught and tagged with acoustic transmitters (from shore: $n=41$; from charter boats: $n=40$ ). A subset of those individuals (shore: $n=12$; charter boats: $n=12$ ) were also tagged with PSATs. There were no significant differences in fork length, fight time, handling time, or water temperature between recreational capture methods (Table 2). Additionally, there was no difference in fight time between reel types. All participating recreational anglers chose to use circle hooks, and hook locations were as follows: jaw, including corner, bottom, and top jaw ( $n=75)$; basihyal $(n=3)$; gut $(n=1)$; throat $(n=1)$; and tail $(n=1)$. Any shark not hooked somewhere in the jaw was considered to be foul-hooked in all subsequent analyses. Anglers chose to remove the hook in all but 3 instances (corner jaw: $n=1$; basihyal: $n=1$; gut: $n=1$ ).

\section{Observed postrelease mortality}

Fifteen blacktip sharks (shore: $n=7$; charter boats: $n=8$ ) died within $10 \mathrm{~d}$ of being released by recreational anglers, resulting in postrelease mortality rates of $17.1 \%$ (95\% CI: 7.2-32.1) for sharks caught from shore and $20.0 \%(95 \%$ CI: 9.1-35.6) for sharks caught from charter boats. No immediate mortalities were observed, with all individuals swimming away at the time of release. Only 4 of the 81 tagged sharks were revived by anglers before being released, and revival times ranged from 1 to $4 \mathrm{~min}$. Six of the 15 sharks considered to have died after release were assigned release conditions of 3 (fair: $n=2$ ) or 4 (poor: $n=4$ ), either because of signs of physical injury or trauma (e.g., excessive bleeding from the hook location) or because of a complete lack of movement during the handling procedure and difficulty swimming postrelease. Additionally, of the sharks considered to have died, one was hooked in the tail and one was hooked in the jaw but with its tail wrapped in the fishing line. Both individuals were reeled in backward, with fight times ( 6 min $35 \mathrm{~s}$ and $8 \mathrm{~min} 57 \mathrm{~s}$, respectively) exceeding the average fight time observed throughout the study (4 min $55 \mathrm{~s}$ [standard deviation (SD) 2 min $27 \mathrm{~s}$ ]). The 7 remaining sharks that died had no signs of injury or trauma and were assigned release conditions of 1 (excellent: $n=6)$ or 2 (good: $n=1$ ).

Five of the 15 sharks that died were tagged with both PSATs and acoustic transmitters (shore: $n=3$; charter boats: $n=2$; Table 3 ); whereas, the mortalities of the other 10 sharks were confirmed with acoustic data only. Data obtained from the PSATs attached to these sharks indicate that 2 PSATs were ingested within $6 \mathrm{~h}$ of being deployed. Shark 9 was actively swimming when its PSAT was ingested $6 \mathrm{~h}$ postrelease (Fig. 2A). This PSAT recorded fluctuating pressure $(0-97,200 \mathrm{~Pa})$ and light intensity (93-384) for the $6 \mathrm{~h}$ prior to ingestion, variations that are consistent with vertical movements in the water column during daytime hours. Subsequent to its ingestion, the tag provided data that indicate darkness for $3 \mathrm{~d}$ followed by a 
Table 2

Capture characteristics, blood chemistry characteristics, and postrelease mortality rates for blacktip sharks (Carcharhinus limbatus) caught with rod and reel by recreational anglers from shore and from charter boats in the coastal waters of South Carolina and Florida between May and October 2017 and between February and October 2018. Mean values are provided with standard deviations in parentheses. Once caught, sharks were tagged and measured, and blood samples were taken from them. Upon release, the condition of sharks was assessed (see Table 1). $\mathrm{pH}_{\mathrm{TC}}=$ temperature-corrected blood $\mathrm{pH}$.

\begin{tabular}{|c|c|c|c|c|c|c|c|c|c|}
\hline \multirow[b]{2}{*}{$\begin{array}{l}\text { Capture } \\
\text { method }\end{array}$} & \multicolumn{7}{|c|}{ Capture characteristics } & \multirow{2}{*}{\multicolumn{2}{|c|}{$\begin{array}{l}\text { Postrelease } \\
\text { mortality (\%) }\end{array}$}} \\
\hline & No. tagged & $\begin{array}{c}\text { Fight } \\
\text { time (min) }\end{array}$ & $\begin{array}{l}\text { Handling } \\
\text { time (min) }\end{array}$ & $\begin{array}{c}\text { Water } \\
\text { temp. }\left({ }^{\circ} \mathrm{C}\right)\end{array}$ & $\begin{array}{l}\text { Proportion } \\
\text { female (\%) }\end{array}$ & $\begin{array}{l}\text { Fork length } \\
(\mathrm{cm})\end{array}$ & $\begin{array}{l}\text { Release } \\
\text { condition }\end{array}$ & & \\
\hline Charter & 40 & $4.75(2.02)$ & $3.55(1.22)$ & $26.9(2.5)$ & 71 & $124.2(19.2)$ & $1.4(0.7)$ & 20 & \\
\hline \multirow[t]{2}{*}{ Shore } & 41 & $5.09(2.82)$ & $3.33(1.16)$ & $27.7(2.6)$ & 77 & $124.5(24.4)$ & $2.4(1.0)$ & & \\
\hline & \multicolumn{2}{|c|}{ Acid-base status } & & \multicolumn{6}{|c|}{ Plasma electrolytes and metabolites } \\
\hline $\begin{array}{l}\text { Capture } \\
\text { method }\end{array}$ & $\mathrm{pH}_{\mathrm{TC}}$ & $\begin{array}{l}\text { Lactate } \\
(\mathrm{mmol} / \mathrm{L})\end{array}$ & $\begin{array}{c}\text { Hematocrit } \\
(\%)\end{array}$ & $\begin{array}{c}\mathrm{Na}^{+} \\
(\mathrm{mmol} / \mathrm{L})\end{array}$ & $\begin{array}{c}\mathrm{Cl}^{-} \\
(\mathrm{mmol} / \mathrm{L})\end{array}$ & $\begin{array}{c}\mathrm{K}^{+} \\
(\mathrm{mmol} / \mathrm{L})\end{array}$ & $\begin{array}{c}\mathrm{Ca}^{2+} \\
(\mathrm{mmol} / \mathrm{L})\end{array}$ & $\begin{array}{c}\mathrm{Mg}^{2+} \\
(\mathrm{mmol} / \mathrm{L})\end{array}$ & $\begin{array}{l}\text { Glucose } \\
\text { (mg/dL) }\end{array}$ \\
\hline Charter & $7.34(0.08)$ & $2.01(0.87)$ & $25.2(2.1)$ & $273.1(9.2)$ & $267.3(7.3)$ & $5.7(0.7)$ & $2.8(0.1)$ & $1.1(0.2)$ & $56.3(5.9)$ \\
\hline Shore & $7.33(0.10)$ & $1.74(1.07)$ & $24.1(3.0)$ & $273.4(7.4)$ & $266.5(6.0)$ & $5.3(0.7)$ & $2.7(0.2)$ & $1.1(0.3)$ & $58.3(4.9)$ \\
\hline
\end{tabular}

\section{Table 3}

Characteristics of the capture of blacktip sharks (Carcharhinus limbatus) tagged with both pop-off satellite archival tags and acoustic transmitters in the coastal waters of South Carolina and Florida between May and October 2017 and between February and October 2018. Upon release, the condition of sharks was assessed (see Table 1). Asterisks (*) indicate sharks that, through the use of data from tags, were determined to have died after release.

\begin{tabular}{|c|c|c|c|c|c|c|c|}
\hline $\begin{array}{l}\text { Shark } \\
\text { ID no. }\end{array}$ & $\begin{array}{l}\text { Capture } \\
\text { method }\end{array}$ & Reel type & $\begin{array}{c}\text { Fight } \\
\text { time (min) }\end{array}$ & $\begin{array}{l}\text { Handling } \\
\text { time (min) }\end{array}$ & $\begin{array}{l}\text { Hook } \\
\text { location }\end{array}$ & $\begin{array}{l}\text { Bleeding } \\
\text { (yes or no) }\end{array}$ & $\begin{array}{l}\text { Release } \\
\text { condition }\end{array}$ \\
\hline 7 & Shore & Spinning & 6.83 & 2.58 & Jaw & $\mathrm{N}$ & 3 \\
\hline $9^{*}$ & Shore & Conventional & 4.38 & 3.75 & Jaw & $\mathrm{Y}$ & 3 \\
\hline 14 & Charter & Conventional & 7.78 & 4.83 & Jaw & $\mathrm{N}$ & 2 \\
\hline 17 & Charter & Conventional & 4.50 & 4.10 & Jaw & $\mathrm{N}$ & 1 \\
\hline 22 & Charter & Spinning & 5.12 & 2.80 & Jaw & $\mathrm{N}$ & 1 \\
\hline 27 & Shore & Spinning & 8.90 & 6.68 & Jaw & $\mathrm{N}$ & 4 \\
\hline 28 & Shore & Conventional & 9.53 & 3.78 & Jaw & $\mathrm{N}$ & 3 \\
\hline $30^{*}$ & Shore & Spinning & 7.00 & 3.07 & Jaw & $\mathrm{N}$ & 1 \\
\hline 31 & Shore & Spinning & 5.82 & 2.72 & Jaw & $\mathrm{N}$ & 2 \\
\hline 34 & Shore & Spinning & 14.07 & 2.83 & Jaw & $\mathrm{N}$ & 4 \\
\hline 40 & Charter & Conventional & 3.13 & 2.80 & Jaw & $\mathrm{N}$ & 1 \\
\hline $43^{*}$ & Charter & Conventional & 4.02 & 3.17 & Throat & $\mathrm{Y}$ & 4 \\
\hline 44 & Charter & Conventional & 6.38 & 3.48 & Jaw & $\mathrm{N}$ & 2 \\
\hline 52 & Shore & Spinning & 5.62 & 2.78 & Jaw & $\mathrm{N}$ & 2 \\
\hline 55 & Shore & Spinning & 7.92 & 4.82 & Jaw & $\mathrm{N}$ & 2 \\
\hline $58^{*}$ & Shore & Spinning & 6.58 & 4.30 & Tail & $\mathrm{N}$ & 4 \\
\hline 59 & Shore & Spinning & 3.40 & 4.05 & Jaw & $\mathrm{N}$ & 2 \\
\hline 61 & Charter & Conventional & 3.92 & 4.70 & Jaw & $\mathrm{N}$ & 2 \\
\hline 63 & Shore & Conventional & 8.45 & 3.78 & Gut & $\mathrm{N}$ & 4 \\
\hline 64 & Charter & Conventional & 6.63 & 3.95 & Jaw & $\mathrm{N}$ & 1 \\
\hline 67 & Charter & Conventional & 6.38 & 2.73 & Jaw & $\mathrm{N}$ & 1 \\
\hline 68 & Charter & Conventional & 3.37 & 2.92 & Jaw & $\mathrm{N}$ & 2 \\
\hline 75 & Charter & Conventional & 5.37 & 5.68 & Jaw & $\mathrm{N}$ & 1 \\
\hline $77^{*}$ & Charter & Conventional & 8.95 & 4.88 & Jaw & $\mathrm{N}$ & 2 \\
\hline
\end{tabular}


return to a cyclical pattern of day and night (Fig. 2A). Brief increases in light intensity during the ingestion period may indicate partial regurgitation of the PSAT. Shark 43, on the other hand, sank to the bottom immediately after release, where it remained for $5 \mathrm{~h}$ before the tag was ingested (Fig. 2B). The data from this PSAT indicate little variation in pressure during the 5 -h period prior to ingestion $(198,400-215,900 \mathrm{~Pa})$ and a complete lack of light intensity (98-109), values consistent with the lack of movement of a dead shark lying on the seafloor. Subsequent to its ingestion, the PSAT attached to shark 43 provided data that indicate darkness for $4.5 \mathrm{~d}$ followed by a return to a cyclical pattern of day and night, similar to what was observed for shark 9 (Fig. 2B). Because both predation events occurred within $6 \mathrm{~h}$ of capture, they were attributed to capture and included in the estimates of mortality.

Of the 24 PSATs deployed, all but 2 PSATs sent data to the Argos satellite system, and 12 PSATs were physically recovered-including 1 of the 2 PSATs that did not transmit data. Excluding the PSATs deployed on the 5 sharks that died, 12 PSATs detached prematurely and 6 PSATs were retained for the entire 28-d deployment. Tag retention periods ranged from 17 min to $28 \mathrm{~d}$ (mean: $11.8 \mathrm{~d}$ [SD 10.6]). The PSAT pressure profiles indicate that none of the premature detachments resulted from tags remaining at a constant depth; when a PSAT stays at the same depth, the burning of the release pin is triggered. Therefore, the 2 most plausible explanations for the premature detachments are that the anchors were pulled out of the dorsal musculature (e.g., as a result of tag consumption by a predator) or that the tethers broke. Two of the 12 PSATs that were physically recovered, both of which detached prematurely, had numerous bite marks on them, indicating that the tags were bitten off. Survival for individuals whose PSATs were shed prematurely (i.e., <10 d after release) was confirmed by using acoustic telemetry (Table 4).

The data obtained from the acoustic transmitters associated with the 5 double-tagged sharks that died indicate the same survivorship outcomes as the data from the PSATs (Fig. 3). None of the acoustic transmitters that were attached to sharks determined to be dead by using data from PSATs were detected on an acoustic receiver more than $5 \mathrm{~d}$ postrelease (Table 4). Both of the acoustic transmitters associated with the PSATs that were ingested were detected on acoustic receivers during the period that the PSAT was inside of the stomach of the predator or scavenger (the PSAT-ingestion period was determined by a lack of light intensity, relative stability of temperature, and continuation of vertical movements indicated by changes in pressure). However, the acoustic transmitters were not detected following regurgitation of the PSATs (within $5 \mathrm{~d}$ of ingestion), and the last acoustic detections for both tags were recorded within $9 \mathrm{~km}$ (5 nautical miles)

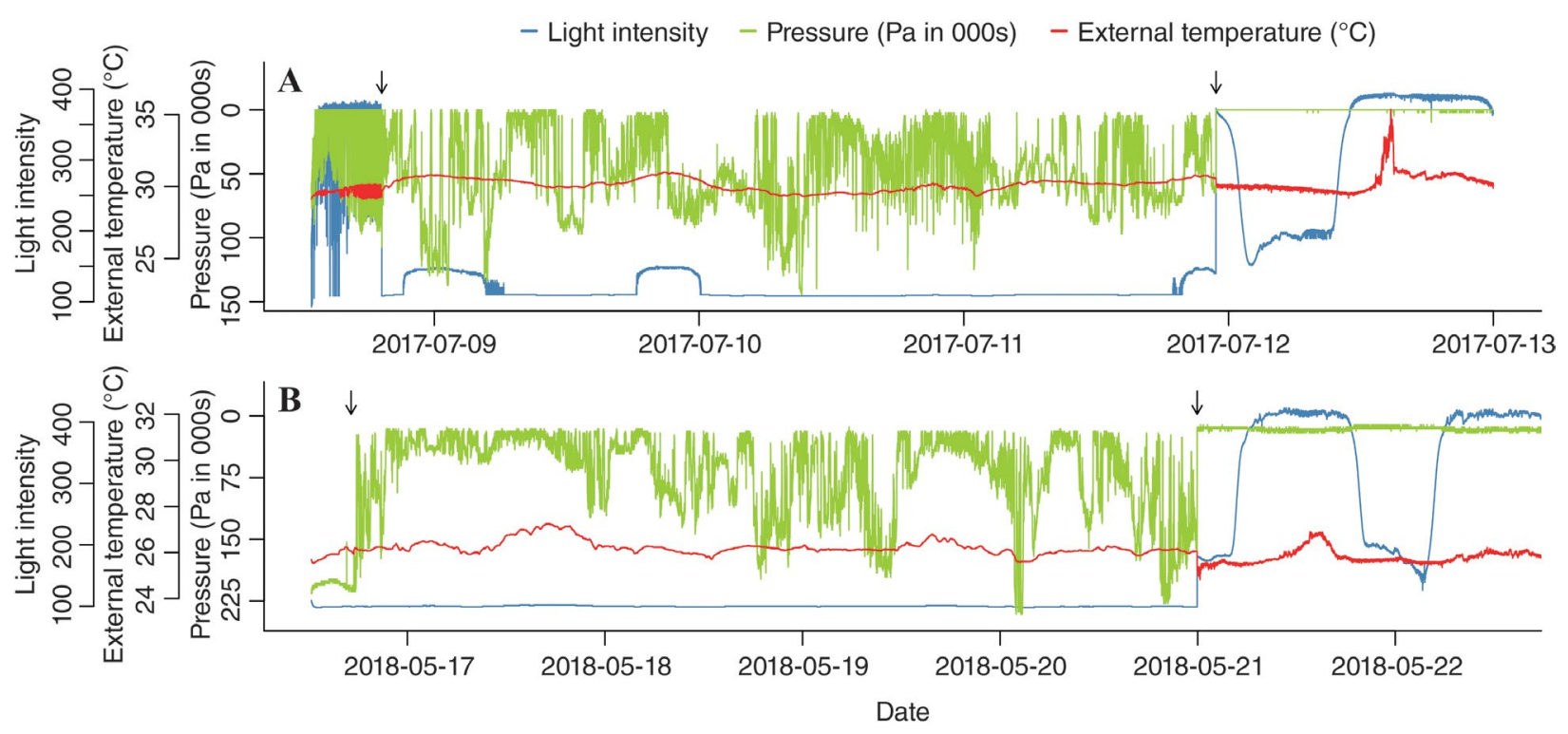

Figure 2

Pressure, external temperature, and light intensity profiles from pop-off satellite archival tags (PSATs) attached to 2 blacktip sharks (Carcharhinus limbatus) during (A) July 2017 (shark 9) and (B) May 2018 (shark 43) in the coastal waters of South Carolina and Florida, both showing a period of ingestion by another shark. Green, red, and blue lines indicate pressure, external temperature, and light intensity, respectively. Shark 9 was actively swimming at the time of ingestion, $6 \mathrm{~h}$ after release. Shark 43 sank to the ocean floor immediately following release, and it remained there for $5 \mathrm{~h}$ prior to ingestion. Both PSATs were regurgitated within $5 \mathrm{~d}$ of ingestion. The first black arrow in each panel denotes the time of assumed predation, and the second black arrow denotes the time of assumed regurgitation. 


\begin{tabular}{|c|c|c|c|c|}
\hline \multicolumn{5}{|c|}{ Table 4} \\
\hline \multicolumn{5}{|c|}{$\begin{array}{l}\text { Summary of results from survivorship analysis based on data from pop-off satel- } \\
\text { lite archival tags (PSATs) and acoustic transmitters deployed on blacktip sharks } \\
\text { (Carcharhinus limbatus) in the coastal waters of South Carolina and Florida } \\
\text { between May and October } 2017 \text { and between February and October } 2018 \text {. Asterisks } \\
\text { (*) indicate sharks that were determined to have died after release. The dagger ( } \dagger \text { ) } \\
\text { indicates an individual whose PSAT never transmitted data to the Argos satellite } \\
\text { system and was never recovered; consequently, data were not available (NA) for this } \\
\text { individual. }\end{array}$} \\
\hline \multirow[b]{2}{*}{$\begin{array}{l}\text { Shark } \\
\text { ID no. }\end{array}$} & \multirow[b]{2}{*}{$\begin{array}{l}\text { Duration } \\
\text { of PSAT } \\
\text { deployment } \\
\text { (d) }\end{array}$} & \multicolumn{3}{|c|}{ Acoustic transmitter characteristics } \\
\hline & & $\begin{array}{l}\text { No. of detections } \\
\text { while PSAT } \\
\text { attached (no. of } \\
\text { unique receivers) }\end{array}$ & $\begin{array}{l}\text { No. of detections } \\
\text { after PSAT } \\
\text { detached (no. of } \\
\text { unique receivers) }\end{array}$ & $\begin{array}{c}\text { No. of days } \\
\text { between dates } \\
\text { of tagging and } \\
\text { last detection }\end{array}$ \\
\hline 7 & 8.29 & $0(0)$ & $1163(21)$ & 301 \\
\hline $9^{*}$ & 3.42 & $150(5)$ & $0(0)$ & 3 \\
\hline 14 & 10.92 & $44(4)$ & $3296(52)$ & 413 \\
\hline 17 & 4.63 & $5(1)$ & $1271(12)$ & 206 \\
\hline 22 & 4.21 & $21(5)$ & $3022(28)$ & 213 \\
\hline 27 & 1.17 & $21(1)$ & 309 (15) & 219 \\
\hline $28^{\dagger}$ & NA & NA & $9368(104)$ & 637 \\
\hline $30^{*}$ & 0.01 & $0(0)$ & $0(0)$ & 0 \\
\hline 31 & 8.25 & $0(0)$ & $10,167(72)$ & 428 \\
\hline 34 & 7.25 & $0(0)$ & $289(12)$ & 103 \\
\hline 40 & 16.13 & $858(3)$ & $462(11)$ & 64 \\
\hline $43^{*}$ & 4.46 & $41(3)$ & $0(0)$ & 2 \\
\hline 44 & 5.63 & $48(3)$ & $2400(29)$ & 183 \\
\hline 52 & 27.46 & $483(4)$ & $4475(50)$ & 333 \\
\hline 55 & 27.33 & $1(1)$ & 7932 (23) & 270 \\
\hline $58^{*}$ & 0.04 & $0(0)$ & $0(0)$ & 0 \\
\hline 59 & 5.88 & $71(3)$ & $307(5)$ & 23 \\
\hline 61 & 12.92 & $1911(6)$ & $10,889(53)$ & 321 \\
\hline 63 & 27.33 & $30(4)$ & $28(3)$ & 123 \\
\hline 64 & 27.42 & $61(4)$ & $1930(26)$ & 185 \\
\hline 67 & 9.68 & $125(5)$ & $721(14)$ & 135 \\
\hline 68 & 27.04 & $1300(2)$ & $11,748(63)$ & 305 \\
\hline 75 & 27.29 & $174(7)$ & 1609 (17) & 68 \\
\hline $77^{*}$ & 0.02 & $91(2)$ & $40(3)$ & 3 \\
\hline
\end{tabular}

of the location where the PSATs surfaced-indicating that both the PSATs and acoustic transmitters were ingested and regurgitated at the same time.

Along the southeastern coast of the United States, 286,683 acoustic detections were recorded by acoustic receivers (Suppl. Fig. 2), and each acoustic transmitter was detected an average of 3542 times (SD 4285). Filtering, based on a 15-min isolation interval, identified 323 false detections $(0.11 \%)$, which were subsequently removed from the data set. The greatest movement detected by using acoustic telemetry was from waters off the Hudson Shelf in New York to waters near Miami, Florida (straight-line distance of $1734 \mathrm{~km}$ ). Fifteen of the 19 double-tagged sharks that survived were detected by acoustic receivers while their PSATs were still attached, and all 19 sharks were detected after their PSATs detached. Additionally, for the individual whose PSAT did not transmit data and was not recovered,
9368 acoustic detections were recorded by 104 different acoustic receivers over $637 \mathrm{~d}$, ranging from Back Sound, North Carolina, to Fort Pierce, Florida, and verifying survival of this shark.

\section{Physiological effects of capture}

Fight time had a significant effect on blood $\mathrm{pH}$, hematocrit, lactate, potassium, and glucose. Blood $\mathrm{pH}$ decreased significantly $(P=0.02$, coefficient of multiple determination $\left[R^{2}\right]=0.11$; Fig. $\left.4 \mathrm{~A}\right)$, and lactate $\left(P=0.00, R^{2}=0.40\right.$; Fig. $\left.4 \mathrm{~B}\right)$, hematocrit $\left(P=0.01, R^{2}=0.16\right.$; Fig. $\left.4 \mathrm{C}\right)$, potassium $(P=0.02$, $R^{2}=0.10$; Fig. 4D), and glucose $\left(P=0.02, R^{2}=0.11\right.$; Fig. $\left.4 \mathrm{E}\right)$ increased significantly with increasing fight times in sharks caught from shore. Lactate $\left(P=0.00, R^{2}=0.45\right.$; Fig. 4B) increased significantly with increasing fight times for sharks caught from charter boats. However, the aforementioned relationships between fight time and blood $\mathrm{pH}$, 


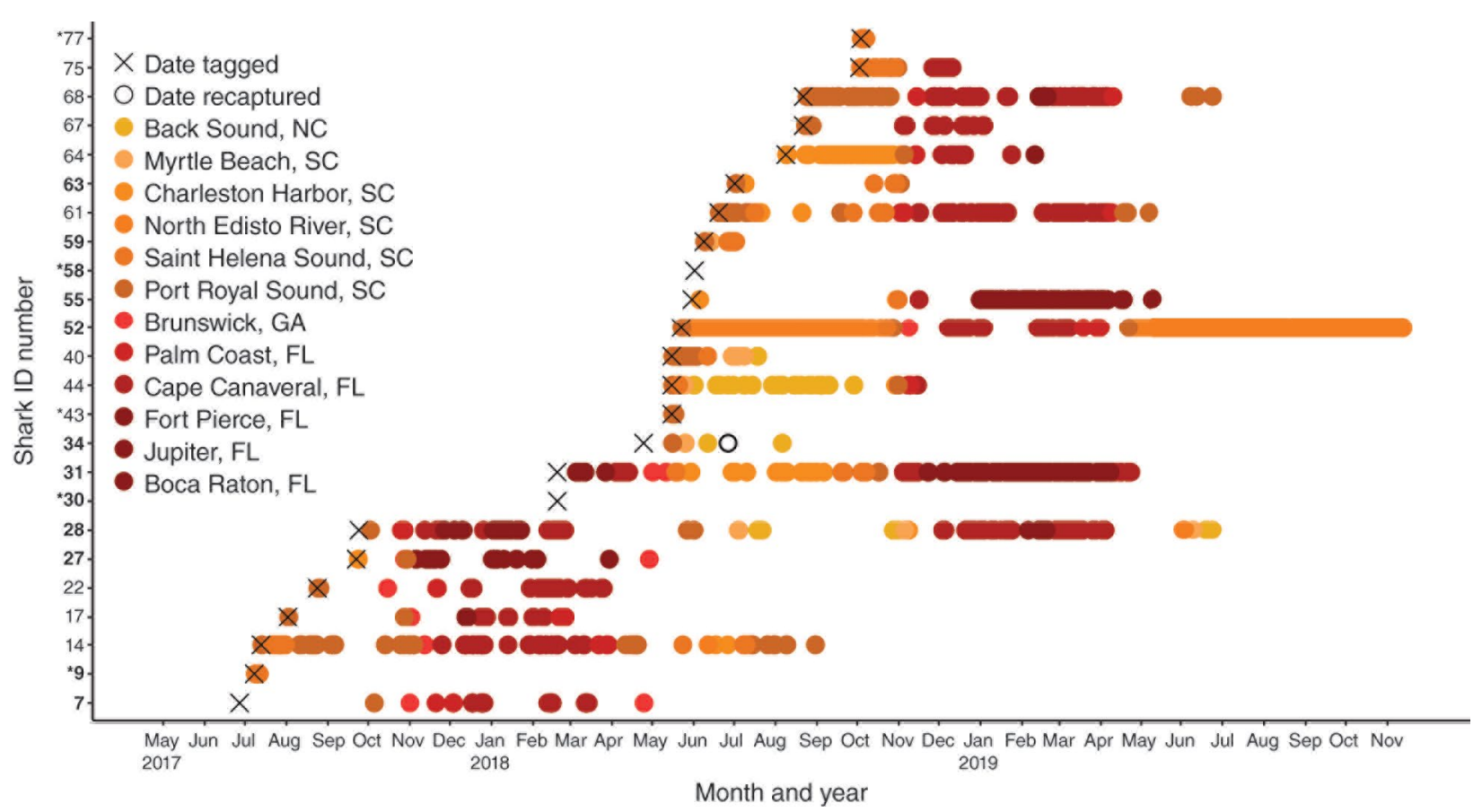

Figure 3

Detections of acoustic transmitters attached to 24 blacktip sharks (Carcharhinus limbatus) that were also tagged with popoff satellite archival tags (PSATs) from June 2017 through December 2019 off the coast of the southeastern United States, by month and location. Each line of circles begins at the date tagged and shows the movement patterns of sharks over time. Asterisks next to shark ID numbers indicate the 5 sharks determined to have died after release by using PSAT data. The ID numbers for sharks caught from shore appear in bold, and the ID numbers for sharks caught from charter boats are not in bold.

hematocrit, potassium, and glucose were relatively weak (as indicated by relatively low $R^{2}$ values). There was no change in sodium, chloride, calcium, or magnesium associated with fight time for either capture method $(P>0.05)$. The effect of fight time on any of the blood chemistry characteristics did not differ between capture methods (ANCOVA: P>0.05; Fig. 4, A-E).

\section{Predicted postrelease mortality}

The GLM analysis determined that a model including both $\mathrm{pH}$ and glucose provided the best fit to binary PRM data for all sharks combined ( $n=81$; AIC for full model=74.96, AIC for reduced model=71.24) and to data for sharks caught from shore ( $n=41$; full-model AIC $=39.65$, reducedmodel AIC=36.47), and a model including only potassium provided the best fit to data for sharks caught from charter boats ( $n=40$; full-model $\mathrm{AIC}=43.13$, reduced-model AIC=38.40). None of the blood chemistry characteristics were a significant predictor of mortality in any of the 3 best-fit models $(P>0.05)$.

With respect to predicting PRM by using the observed capture characteristics, a GLM model including only release condition provided the best fit to binary PRM data for all sharks combined ( $n=81$; full-model $\mathrm{AIC}=72.52$, reduced-model $\mathrm{AIC}=63.24$ ) and to data for sharks caught from charter boats ( $n=40$; full-model $\mathrm{AIC}=39.63$, reducedmodel AIC=33.39). A model including water temperature $(P=0.06)$, fight time $(P=0.01)$, and release condition $(P=0.02)$ provided the best fit to data for sharks caught from shore ( $n=41$; full-model $\mathrm{AIC}=41.33$, reduced-model $\mathrm{AIC}=34.34)$.

Hook location did not have a significant effect on the distribution of survivors and mortalities (Fisher's exact test: $P=0.07$ ), likely a result of small sample sizes for hook locations other than the jaw. Of the individuals hooked in the jaw (including corner, bottom, or top jaw), $16.0 \%$ died; whereas, $33.3 \%$ of individuals hooked in the basihyal died and $100 \%$ of individuals hooked either in the throat or tail died. The assigned release condition did not have a significant effect on the distribution of survivors and mortalities (Fisher's exact test, $P=0.13$ ). Of the individuals assigned a release condition of excellent, $18.4 \%$ died; whereas, $8.3 \%, 20.0 \%$, and $44.4 \%$ of individuals assigned a condition of good, fair, and poor died, respectively (Fig. 5).

\section{Discussion}

The results of this study provide insights into both the physical and physiological effects of recreational rod-and-reel 


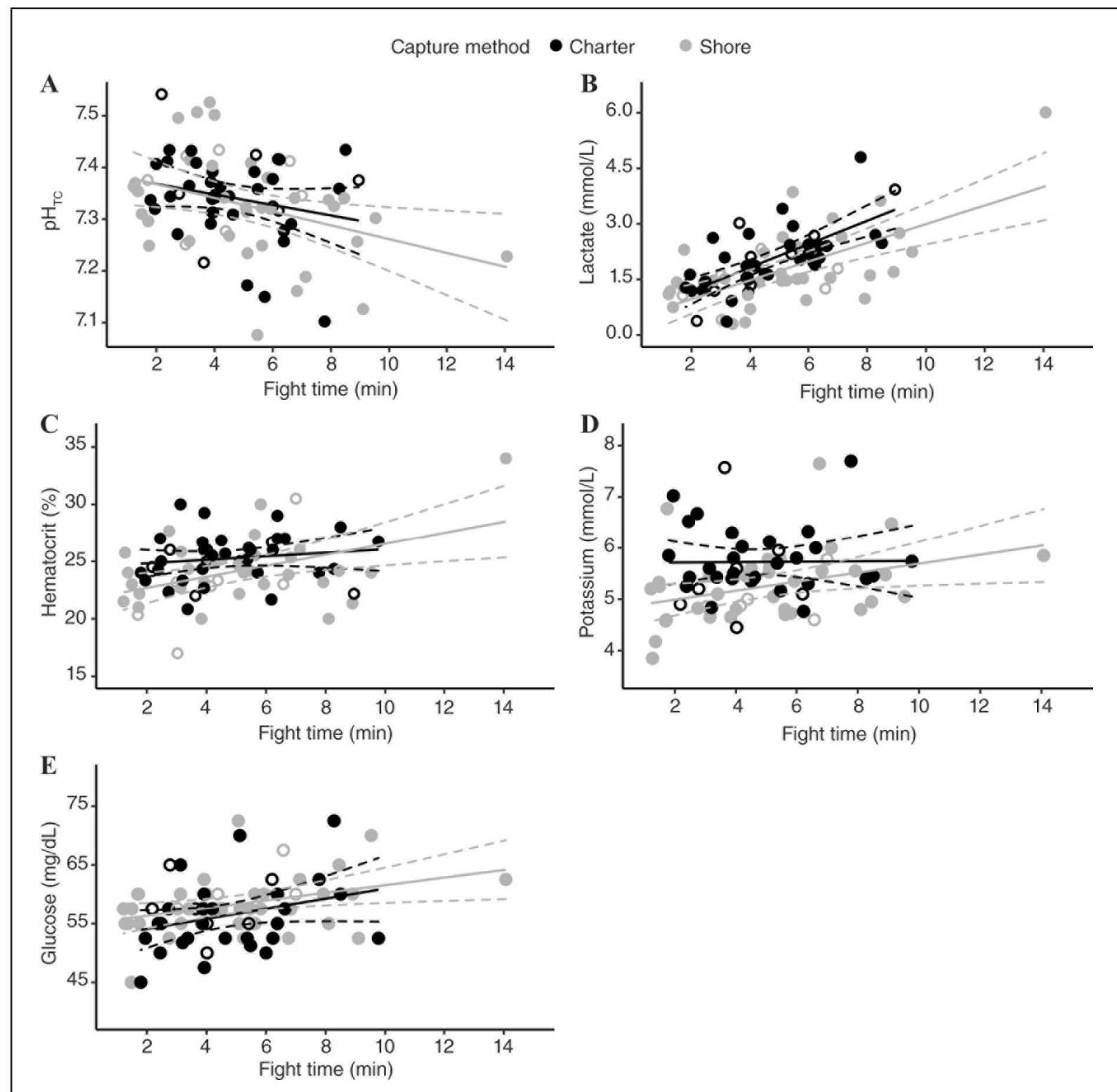

Figure 4

Linear regressions fitted to data of blood chemistry characteristics versus fight time for blacktip sharks (Carcharhinus limbatus) caught by recreational anglers in the coastal waters of South Carolina and Florida between May and October 2017 and between February and October 2018. Blood chemistry characteristics are (A) temperature-corrected blood $\mathrm{pH}\left(\mathrm{pH}_{\mathrm{TC}}\right),(\mathbf{B})$ lactate, $(\mathbf{C})$ hematocrit, $(\mathbf{D})$ potassium, and (E) glucose. Fight time refers to the time from the initial strike until the time the shark was secured by anglers. Gray circles represent sharks caught from shore, and black circles represent sharks caught from charter boats. Open circles indicate sharks determined to have died after release. Solid lines indicate regression model predictions, and dashed lines indicate $95 \%$ confidence intervals.

capture on the blacktip shark, and how these effects influence PRM rates. Furthermore, this study produced data on the physiological stress and mortality experienced by individuals of this shark species when caught from shore, in a recreational fishery receiving increasing management and conservation attention. Postrelease mortality rates were $17.1 \%$ for sharks caught from shore and $20.0 \%$ for sharks caught from charter boats, and the results of survivorship analysis based on data from acoustic transmitters were consistent with results inferred from data from PSATs, validating our use of acoustic transmitters to assess PRM. Significant physiological changes were documented in the blood chemistry of sharks, and changes were influenced by fight time. 


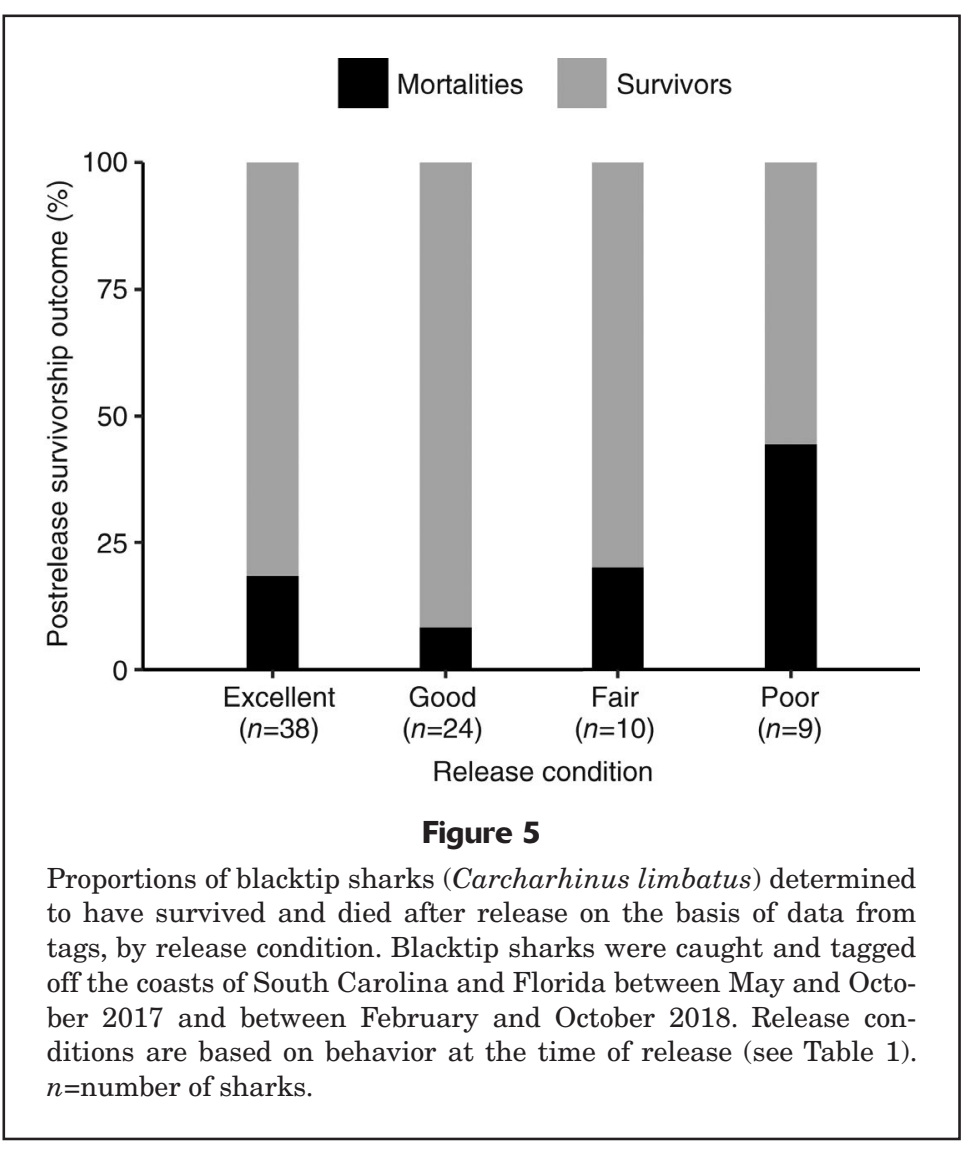

takes an average of $10.5 \mathrm{~h}$ (Whitney et al., 2016). This result is also consistent with those of other studies that indicate that most capture-related mortalities of sharks occur 1-4 h after release (Heberer et al., 2010; Marshall et al., 2015; Whitney et al., 2017).

Acoustic receiver coverage along the eastern coast of the United States is not consistent, and many acoustic receivers tend to be closer to shore, given the inherent issues with anchoring receivers in open water. Therefore, it is possible that surviving blacktip sharks, not tagged with a PSAT, avoided acoustic detection (e.g., by staying farther offshore) and as a result were considered to be dead in our study. Additionally, it is possible that consumption of acoustic tags, without predation on blacktip sharks themselves, could explain the lack of acoustic detections for individuals that were tagged only with acoustic transmitters and were considered to have died during our study. Because 10 of the 15 mortalities were confirmed from acoustic data alone, the mortality rates presented herein may be overestimated. However, given the preference of blacktip sharks for nearshore waters and observed high detection rates of blacktip sharks tagged with acoustic transmitters in this study (Table 4) and in other ongoing studies (Bowers ${ }^{5}$ ), the probability of a tagged blacktip shark escaping detection during migration is likely low.

\section{Postrelease mortality}

The PRM rates observed in this study are higher than PRM rates reported for many other shark species caught on rod and reel, such as the rates of $10 \%$ for shortfin makos (Isurus oxyrinchus) (French et al., 2015), 12.5\% for juvenile lemon sharks (Negaprion brevirostris) (Danylchuk et al., 2014), and 10\% for Atlantic sharpnose sharks (Rhizoprionodon terraenovae) (Gurshin and Szedlmayer, 2004). In addition, the observed PRM rates are approximately twice as high as the rate of $9.7 \%$ reported by Whitney et al. (2017) for blacktip sharks caught in the charter-boat-based recreational fishery in Florida. This difference in PRM rates may be partially attributable to the higher incidence of physical injury or trauma $(n=6)$, foul-hooking $(n=6)$, and live predation $(n=1)$ observed in our study but not by Whitney et al. (2017).

All sharks captured in our study were caught by recreational anglers using their personal fishing equipment; therefore, a wide range of angler experience and of gear types and strengths were sampled. No at-vessel or atshore mortalities were observed, and all 5 of the mortality events inferred from PSATs occurred within $6 \mathrm{~h}$ of release. This result indicates that mortalities associated with rodand-reel capture of blacktip sharks do not occur at landing but can occur up to $6 \mathrm{~h}$ postrelease and is consistent with results from previous research on blacktip sharks indicating that behavioral recovery from rod-and-reel capture

\section{Predation postrelease}

Postrelease mortality rates of blacktip sharks may be influenced by the presence of larger shark species, such as the tiger shark (Galeocerdo cuvier), great hammerhead (Sphyrna mokarran), and bull shark (C. leucas), that are commonly found off the southeastern coast of the United States (Ulrich et al., 2007; Castro, 2011). In our study, data profiles from PSATs deployed on 2 blacktip sharks (sharks 9 and 43) indicate that the tags were ingested within $6 \mathrm{~h}$ of release. Shark 9 was actively swimming at the time of PSAT ingestion, but it may have been behaving erratically given that the PSAT was ingested $(6 \mathrm{~h}$ after release) within the behavioral recovery window for blacktip sharks caught on rod and reel (mean: $10.5 \mathrm{~h}$; Whitney et al., 2016). Shark 43 sank to the ocean floor immediately after release, where it remained for $5 \mathrm{~h}$ until the PSAT was scavenged. It was impossible to determine with certainty if only the PSATs were consumed or if the PSATs and the blacktip sharks were consumed. However, the acoustic data obtained from the tags deployed on both of these individuals (sharks 9 and 43) indicate that the acoustic transmitters were ingested and regurgitated at the same time as the PSATs. Therefore, it is unlikely that

\footnotetext{
${ }^{5}$ Bowers, B. 2019. Personal commun. Charles E. Schmidt Coll. Sci., Fla. Atl. Univ., 777 Glades Rd., Boca Raton, FL 33431.
} 
both the PSATs and acoustic transmitters were ingested without predation upon the blacktip shark itself.

Although these events could be the first instances of live predation on a blacktip shark recorded by a PSAT, Lear and Whitney (2016) documented postrelease scavenging of a blacktip shark by a larger shark. In addition, live predation events on other species are prevalent in the literature; for example, such events have been reported for the white marlin (Kajikia albida) and opah (Lampris guttatus) (Kerstetter et al., 2004), the albacore (Thunnus alalunga) (Cosgrove et al., 2015), and the tope (Galeorhinus galeus) (Rogers et al., 2017; Tolentino et al., 2017). Many shark species have been described to evert their stomachs in response to physical stimuli, such as the ingestion of hard, inedible objects (e.g., the shortfin mako; Brunnschweiler et al., 2011), and the timing between the ingestion and regurgitation events in our study (3.0 and $4.5 \mathrm{~d}$ ) is similar to that reported in other studies (Kerstetter et al., 2004; Brunnschweiler, 2009; Lear and Whitney, 2016; Rogers et al., 2017). It is possible that the presence of an external PSAT could increase predation risk, because of an increase in visibility to predators (Manabe et al., 2011; Béguer-Pon et al., 2012). However, because both predation events observed in our study occurred in highly turbid waters with low visibility $(<0.5 \mathrm{~m})$ off South Carolina, the large sharks that prey on blacktip sharks in such areas likely do not rely heavily on vision to target prey (Gardiner et al., 2014). Given that blacktip sharks are known to form large aggregations (Castro, 2011), it is possible that individuals of conspecifics could have dislodged other PSATs without consuming the blacktip sharks, possibly explaining the premature PSAT detachments observed in our study (Rogers et al., 2017).

\section{Validation of acoustic telemetry for assessment of survival}

Some individuals were tagged with both PSATs and acoustic transmitters in our study, and the results indicate that acoustic transmitters can be used effectively to assess PRM in migratory, coastal shark species released in regions with a high prevalence of acoustic receivers. In our study, data obtained from acoustic transmitters indicate the same survivorship outcome as data obtained from the PSATs for all double-tagged individuals. In particular, none of the 5 sharks for which mortalities were confirmed with data from the PSATs were detected on an acoustic receiver more than $10 \mathrm{~d}$ postrelease, although all 18 of the individuals that were confirmed to have survived with data from the PSATs, including those with PSATs that were shed prematurely, were detected from 23 to $637 \mathrm{~d}$ postrelease (mean: 238.4 d [SD 150.3]) (Table 4).

The electronic tags designed for assessing PRM (e.g., PSATs) can be cost prohibitive (Musyl et al., 2011; Whitney et al., 2016; Rogers et al., 2017), forcing many researchers to use relatively small sample sizes or to deploy tags only on individuals that they believe have a chance at survival (i.e., they do not want to "waste" a tag on an individual that they believe will die), potentially biasing PRM estimates (Rogers et al., 2017). Additionally, the vast majority of PSATs $(\sim 80 \%)$ are shed before their programmed pop-up date (Arnold and Dewar, 2001; Gunn and Block, 2001), and others often fail to transmit data to the satellite system altogether (Musyl et al., 2011). In our study, 67\% of PSATs deployed on surviving sharks were shed prematurely, and 2 PSATs failed to send data to the satellite system (failure rate of $8.3 \%$ ). Therefore, in addition to the cost of such electronic tags precluding the use of large sample sizes, researchers also face relatively high tag failure rates.

The lower cost of acoustic transmitters could allow for the inclusion of much larger sample sizes and, therefore, more robust assessments of PRM. Additionally, the smaller size of acoustic transmitters, compared with the sizes of other electronic tags (e.g., PSATs), could reduce any potential effects of the tag on a shark's behavior postrelease and, as a result, are likely more appropriate for the assessment of PRM in smaller fish species. Although the effectiveness of using acoustic transmitters to assess PRM depends on the prevalence of acoustic receivers, the number of acoustic receivers deployed along the eastern coast of the United States is increasing (Kneebone et al., 2013), and the rising number of receivers will likely increase the applicability of this method.

\section{Physiological effects of capture}

The stress experienced by captured sharks has traditionally been quantified through an assessment of the acid-base status of blood. In this study, $\mathrm{pH}$ decreased with increasing fight time for sharks caught from shore, and lactate increased for sharks caught by using both capture methods, indicating that blacktip sharks experienced proton $\left(\mathrm{H}^{+}\right)$loading in blood and tissues due to the dissociation of lactic acid generated by anaerobic glycolysis (Skomal and Mandelman, 2012; Kneebone et al., 2013). These findings indicate that rod-and-reel capture of blacktip sharks results in blood acidosis that is at least partially metabolic in origin, and they are consistent with the results reported by Whitney et al. (2017). Mandelman and Skomal (2009) found that increases in $\mathrm{pCO}_{2}$ explained all of the variation in $\mathrm{pH}$ in blacktip sharks captured with longlines, indicating that acidemia in blacktip sharks caught with longlines is driven strictly by respiratory acidosis. Because measurements of $\mathrm{pCO}_{2}$ made by the i-STAT system have not been validated, we do not report $\mathrm{pCO}_{2}$ values from our study; therefore, the potential contribution of $\mathrm{CO}_{2}$ to the observed acidosis cannot be determined. Regardless, differences in lactate profiles between studies indicate that the origin of the acidosis could be associated with the type of gear used and support the growing awareness that fishery-specific assessments of the stress experienced by captured sharks are necessary (Skomal, 2007; Heberer et al., 2010).

In general, exhaustive exercise leads to elevated concentrations of both glucose (Sherwin et al., 1980; Sheridan and Muir, 1988) and potassium (Medbø and Sejersted, 1990). Catecholamines are responsible for stimulating glucose release from the liver during exercise (i.e., glycogenolysis; Sherwin et al., 1980; Sheridan and Muir, 1988) to meet 
the energy demands of muscles, and it has been suggested that the mobilization of glucose may be integral to survival (Marshall et al., 2012). Increases in plasma potassium can result from several factors, including a release of potassium from muscle cells due to increased electrical activity (Fenn, 1938; Sejersted and Sjøgaard, 2000) and a decrease in plasma water due to increased intracellular lactate levels that cause a net fluid shift from extracellular to intracellular compartments (van Dijk and Wood, 1988; Wood, 1991). In our study, both glucose and potassium rose with increasing fight times for sharks caught from shore but not for sharks caught from charter boats. Given that fight times did not differ between capture methods, elevated glucose and potassium levels in sharks caught from shore may reflect a higher degree of struggling on the line. Moreover, rhabdomyolysis, a syndrome characterized by muscle necrosis and the release of intracellular electrolytes, often due to muscle trauma associated with intense exercise, can also lead to elevated potassium concentrations (Keltz et al., 2013). The origin of the high glucose and potassium concentrations in sharks caught from shore could simply be a normal response to exercise, but conditions such as rhabdomyolysis cannot be excluded.

The effect of fight time on numerous blood chemistry characteristics for sharks caught from shore $(\mathrm{pH}$, lactate, hematocrit, potassium, and glucose), but not for sharks caught from charter boats (only lactate), could be a result of the tackle (i.e., fishing gear) used by the participating recreational anglers. In particular, the majority of sharks caught from shore were caught with spinning reels (76\%), and the majority of sharks caught from charter boats were caught with conventional level-wind reels (85\%). Because conventional reels typically have a higher drag capacity than spinning reels, making it more difficult for hooked fish to "run," conventional reels may restrict the movement of captured sharks and, as a result, lessen the degree of muscular exertion and metabolic stress. Additionally, many shore-based fishermen put out far more fishing line initially (e.g., a couple hundred yards, in order to reach deeper water) than anglers who fish from charter boats, and the additional line may give the shark more room to run, both vertically and horizontally, in the water column. Although traditional sportfishing ethics has encouraged the use of light tackle to give the fish a "fighting chance," research results indicate that slowly and carefully angling a fish can potentially exacerbate the stress response (Malchoff and $\mathrm{MacNeill}^{6}$ ).

The results of our study support the notion that use of heavy fishing tackle minimizes the fight time and therefore likely reduces the physiological stress experienced by captured sharks. Future research employing the use of serial blood sampling (e.g., sampling before and after handling by anglers) could improve our understanding of the effects of capture on shark species and of how those effects are influenced by both gear type and handling technique.

\footnotetext{
${ }^{6}$ Malchoff, M. H., and D. B. MacNeill. 1995. Guidelines to increase survival of released sport fish. Released fish survival. Sport fish fact sheet, 6 p. Cornell Coop. Ext., Sea Grant, Cornell Univ., Ithaca, NY. [Available from website.]
}

Overall, blacktip sharks caught on rod and reel (this study; Whitney et al., 2017) have relatively less drastic physiological disruptions than individuals caught on longlines (Mandelman and Skomal, 2009; Marshall et al., 2012) and drumlines (Gallagher et al., 2014; Jerome et al., 2018). Mean blood lactate values for blacktip sharks caught on longlines (14.82 mmol/L, Mandelman and Skomal, 2009; $36.8 \mathrm{mmol} / \mathrm{L}$, Marshall et al., 2012) and drumlines ( $8 \mathrm{mmol} / \mathrm{L}$, Gallagher et al., 2014; $6.3 \mathrm{mmol} / \mathrm{L}$, Jerome et al., 2018) are much higher than the mean lactate value reported in our study $(2.48 \mathrm{mmol} / \mathrm{L})$. The concentrations of plasma electrolytes in blacktip sharks caught on longlines (potassium: $10.2 \mathrm{mmol} / \mathrm{L}$; sodium: $298 \mathrm{mmol} / \mathrm{L}$; Marshall et al., 2012) are also higher than the values reported in our study (potassium: $5.5 \mathrm{mmol} / \mathrm{L}$; sodium: $273.3 \mathrm{mmol} / \mathrm{L}$ ). Collectively, the more drastic physiological changes observed in blacktip sharks captured on longlines or drumlines are likely due to the duration of the struggle on the line (e.g., up to $3 \mathrm{~h}$, Mandelman and Skomal, 2009; 2-12 h, Marshall et al., 2012; mean of $46.5 \mathrm{~min}$, Jerome et al., 2018).

\section{Prediction of postrelease mortality}

Estimates of mortality for released fish are critical components for estimation of total mortality and are therefore of critical importance to fisheries managers. Because the direct estimation of PRM across species and gear types is likely unrealistic, previous studies have aimed to predict PRM through the use of blood chemistry characteristics (Moyes et al., 2006; Heberer et al., 2010; Schlenker et al., 2016; Talwar et al., 2017) and various capture characteristics (Manire et al., 2001; Hueter et al., 2006; Musyl and Gilman, 2018). In our study, none of the blood chemistry characteristics could be used to predict mortality with any degree of significance. Because all blood samples were screened for $\mathrm{pH}$, lactate, hematocrit, sodium, chloride, potassium, calcium, magnesium, and glucose, the lack of ability to use any of the blood characteristics to predict mortality indicates that many of the observed mortalities were not a result of the potentially exhaustive exercise associated with struggling on a fishing line.

In general, the assigned release condition was the best predictor of PRM, indicating that many of the sharks that died had observable signs of injury or trauma. Noticeable injuries were often related to the location of the hook and typically involved significant bleeding. However, $18.4 \%$ of individuals assigned a release condition of excellent died postrelease, indicating that many succumbing individuals have no sign of physical injury or trauma and that assignment of release condition can be somewhat subjective.

In our study, 6 of the 81 tagged blacktip sharks were considered to be foul-hooked, with hook locations of the basihyal, throat, gut, and tail. Three of the 6 foul-hooked sharks died within $10 \mathrm{~d}$ of release, for a PRM rate of $50 \%$ for foul-hooked sharks. Hook location has been shown to influence survival in many species (Muoneke and Childress, 1994), and mortality is often associated with damage to gills or visceral tissue caused by deeply embedded hooks (Heberer et al., 2010). All recreational anglers in 
our study chose to use circle hooks-again, no input was provided by the authors on the type or size of hook that should be used. Therefore, it is possible that instances of foul-hooking would have been higher if $\mathrm{J}$ hooks were used (Prince et al., 2002; Promjinda et al. ${ }^{7}$; Pacheco et al., 2011), although Whitney et al. (2017) found no difference in the incidence of foul-hooking or PRM between the use of $\mathrm{J}$ hooks and the use of circle hooks.

The hook location not only can influence PRM through physical trauma (e.g., damage to gills or visceral tissue) but also can impair locomotion and a shark's ability to ventilate properly (Heberer et al., 2010). The blacktip shark is a ram-ventilating species that must move forward to subject its gills to ventilation because the orientation and morphology of elasmobranch gill slits preclude water flow over gills when individuals are pulled backward (Heberer et al., 2010; Wegner et al., 2010). Therefore, sharks hooked in the tail (i.e., caudal fin) or tail-wrapped in the fishing line and reeled in backward experience reduced water flow over the gills and can ventilate only during brief periods of forward swimming. Indeed, in our study, the only shark hooked in the tail died postrelease. Additionally, the shark that was hooked in the jaw but tail-wrapped in the line and dragged backward also died postrelease. The survival implications for sharks hooked in the tail are well-documented; for example, in another study, $78 \%$ of common thresher sharks (Alopias vulpinus) hooked in the tail died postrelease (Sepulveda et al., 2015).

Overall, PRM rates in our study are similar for blacktip sharks captured in recreational fisheries from shore (17.1\%) and from charter boats $(20.0 \%)$ and are higher than PRM rates that have been reported for many other shark species caught on rod and reel. The agreement between the results we obtained from analyzing data from the acoustic transmitters and from the PSATs verify that acoustic transmitters can be used to effectively assess PRM in migratory, coastal shark species released in regions with a high prevalence of acoustic receivers (e.g., the eastern coast of the United States). Significant physiological disruptions in the blood chemistry of sharks were identified, and fight time had a significant effect on $\mathrm{pH}$, lactate, hematocrit, potassium, and glucose. Fifty percent of foul-hooked sharks died postrelease, with important implications for the use of gear and methods that reduce foul-hooking.

\section{Acknowledgments}

We thank all participating recreational fishermen and all acoustic telemetry data contributors, including staff of the FACT and ACT Networks. We are grateful to A. Galloway, A. Bland, C. Morgan, D. Edmunds, C. Innis, and R. Knotek. Additionally, we thank M. Janech, L. Burnett,

\footnotetext{
${ }^{7}$ Promjinda, S., S. Siriraksophon, N. Darumas, and P. Chaidee. 2008. Efficiency of the circle hook in comparison with J-hook in longline fishery. In The ecosystem-based fishery management in the Bay of Bengal, p. 167-180. Dep. Fish., Minist. Agric. Coop., Bangkok, Thailand. [Available from website.]
}

and both the anonymous reviewers for their comments on previous versions of this manuscript. This work was supported by the NOAA Cooperative Research Program (grant no. NA16NMF4540081), the American Elasmobranch Society, and the Slocum-Lunz Foundation. This paper is contribution 829 of the South Carolina Marine Resources Center.

\section{Literature cited}

Ajemian, M. J., P. D. Jose, J. T. Froeschke, M. L. Wildhaber, and G. W. Stunz.

2016. Was everything bigger in Texas? Characterization and trends of a land-based recreational shark fishery. Mar. Coast. Fish. 8:553-566. Crossref

Akaike, $\mathrm{H}$.

1973. Information theory and an extension of the maximum likelihood principle. In 2nd international symposium on information theory (B. N. Petrov and F. Csáki, eds.), p. 267-281. Akad. Kiadó, Budapest.

Arlinghaus, R., and S. J. Cooke.

2009. Recreational fisheries: socioeconomic importance, conservation issues and management challenges. In Recreational hunting, conservation and rural livelihoods: science and practice (B. Dickson, J. Hutton, and W. M. Adams, eds.), p. 39-58. Blackwell Publ., Oxford, UK.

Arnold, G., and H. Dewar.

2001. Electronic tags in marine fisheries research: a 30-year perspective. In Electronic tagging and tracking in marine fisheries reviews: methods and technologies in fish biology and fisheries (J. R. Sibert and J. L. Nielsen, eds.), p. 7-64. Kluwer Acad. Press, Dordrecht, Netherlands.

Bartholomew, A., and J. A. Bohnsack.

2005. A review of catch-and-release angling mortality with implications for no-take reserves. Rev. Fish Biol. Fish. 15:129-154. Crossref

Béguer-Pon, M., J. Benchetrit, M. Castonguay, K. Aarestrup, S. E. Campana, M. J. W. Stokesbury, and J. J. Dodson.

2012. Shark predation on migrating adult American eels (Anguilla rostrata) in the Gulf of St. Lawrence. PLoS ONE 7(10):e46830. Crossref

Bigelow, H. B., and W. C. Schroeder.

1948. Fishes of the western North Atlantic. Part 1: lancelets, cyclostomes, and sharks, 576 p. Mem. Sears Found. Mar. Res., Yale Univ. Press, New Haven, CT.

Bonfil, R.

1994. Overview of world elasmobranch fisheries. FAO Fish. Tech. Pap. 341, 119 p. FAO, Rome.

Brill, R., P. Bushnell, S. Schroff, R. Seifert, and M. Galvin.

2008. Effects of anaerobic exercise accompanying catch-andrelease fishing on blood-oxygen affinity of the sandbar shark (Carcharhinus plumbeus, Nardo). J. Exp. Mar. Biol. Ecol. 354:132-143. Crossref

Brooks, E. J., J. W. Mandelman, K. A. Sloman, S. Liss, A. J. Danylchuk, S. J. Cooke, G. B. Skomal, D. P. Philipp, D. W. Sims, and C. D. Suski.

2012. The physiological response of the Caribbean reef shark (Carcharhinus perezi) to longline capture. Comp. Biochem. Physiol. A. 162:94-100. Crossref

Brunnschweiler, J. M.

2009. Tracking free-ranging sharks with hand-fed intragastric acoustic transmitters. Mar. Freshw. Behav. Physiol. 42:201-209. Crossref 
Brunnschweiler, J. M., F. Nielsen, and P. Motta.

2011. In situ observation of stomach eversion in a linecaught shortfin mako (Isurus oxyrinchus). Fish. Res. 109:212-216. Crossref

Castro, J. I.

1996. Biology of the blacktip shark (Carcharhinus limbatus) off the southeastern United States. Bull. Mar. Sci. 59:508-522.

2011. Blacktop shark, Carcharhinus limbatus. In The sharks of North America, p. 432-437. Oxford Univ. Press, New York.

Compagno, L. J. V.

1984. FAO species catalog. Vol. 4. Sharks of the world. An annotated and illustrated catalogue of shark species known to date. Part 2. Carcharhiniformes. FAO Fish. Synop. 125, p. 251-655. FAO, Rome.

Cooke, S. J., and I. G. Cowx.

2004. The role of recreational fishing in global fish crises. BioScience 54:857-859. Crossref

Cooke, S. J., and H. L. Schramm.

2007. Catch-and-release science and its application to conservation and management of recreational fisheries. Fish. Manage. Ecol. 14:73-79. Crossref

Cosgrove, R., I. Arregui, H. Arrizabalaga, N. Goni, and J. D. Nielson. 2015. Predation of pop-up satellite archival tagged albacore (Thunnus alalunga). Fish. Res. 162:48-52. Crossref

Danylchuk, A. J., C. D. Suski, J. W. Mandelman, K. J. Murchie,

C. R. Haak, A. M. L. Brooks, and S. J. Cooke.

2014. Hooking injury, physiological status and short-term mortality of juvenile lemon sharks (Negaprion bevirostris) following catch-and-release recreational angling. Conserv. Physiol. 2:cot036. Crossref

Dapp, D. R., T. I. Walker, C. Huveneers, and R. D. Reina.

2016. Respiratory mode and gear type are important determinants of elasmobranch immediate and post-release mortality. Fish Fish. 17:507-524. Crossref

Donaldson, M. R., R. Arlinghaus, K. C. Hanson, and S. J. Cooke.

2008. Enhancing catch-and-release science with biotelemetry. Fish Fish. 9:79-105. Crossref

Ellis, J. R., S. R. M. Phillips, and F. Poisson.

2017. A review of capture and post-release mortality of elasmobranchs. J. Fish Biol. 90:653-722. Crossref

Fenn, W. O.

1938. Factors affecting the loss of potassium from stimulated muscles. Am. J. Physiol. 124:213-229. Crossref

French, R. P., J. Lyle, S. Tracey, S. Currie, and J. M. Semmens.

2015. High survivorship after catch-and-release fishing suggests physiological resilience in the endothermic shortfin mako shark (Isurus oxyrinchus). Conserv. Physiol. 3:cov044. Crossref

Gallagher, A. J., L. H. Frick, P. G. Bushnell, R. W. Brill, and

J. W. Mandelman.

2010. Blood gas, oxygen saturation, $\mathrm{pH}$, and lactate values in elasmobranch blood measured with a commercially available portable clinical analyzer and standard laboratory instruments. J. Aquat. Anim. Health 22:229-234. Crossref

Gallagher, A. J., J. E. Serafy, S. J. Cooke, and N. Hammerschlag.

2014. Physiological stress response, reflex impairment, and survival of five sympatric shark species following experimental capture and release. Mar. Ecol. Prog. Ser. 496:207-218. Crossref

Gardiner, J. M., J. Atema, R. E. Hueter, and P. J. Motta.

2014. Multisensory integration and behavioral plasticity in sharks from different ecological niches. PLoS ONE 9(4):e93036. Crossref
Gunn, J., and B. Block.

2001. Advances in acoustic, archival, and satellite tagging of tunas. Fish Physiol. 19:167-224. Crossref

Gurshin, C. W. D., and S. T. Szedlmayer.

2004. Short-term survival and movements of Atlantic sharpnose sharks captured by hook-and-line in the north-east Gulf of Mexico. J. Fish Biol. 65:973-986. Crossref

Harter, T. S., P. R. Morrison, J. W. Mandelman, J. L. Rummer, A. P. Farrell, R. W. Brill, and C. J. Brauner.

2015. Validation of the i-STAT system for the analysis of blood gases and acid-base status in juvenile sandbar shark (Carcharhinus plumbeus). Conserv. Physiol. 3:cov002. Crossref

Heberer, C., S. A. Aalbers, D. Bernal, S. Kohin, B. DiFiore, and C. A. Sepulveda.

2010. Insights into catch-and-release survivorship and stressinduced blood biochemistry of common thresher sharks (Alopias vulpinus) captured in the southern California recreational fishery. Fish. Res. 106:495-500. Crossref

Heupel, M. R., J. M. Semmens, and A. J. Hobday.

2006. Automated acoustic tracking of aquatic animals: scales, design and deployment of listening station arrays. Mar. Freshw. Res. 57:1-13. Crossref

Holbrook, C., T. Hayden, T. Binder, and J. Pye.

2020. glatos: a package for the Great Lakes Acoustic Telemetry Observation System. R package, vers. 0.4.2. [Available from website, accessed April 2020.]

Hueter, R. E., C. A. Manire, J. P. Tyminski, J. M. Hoenig, and D. A. Hepworth.

2006. Assessing mortality of released or discarded fish using a logistic model of relative survival derived from tagging data. Trans. Am. Fish. Soc. 135:500-508. Crossref

Jerome, J. M., A. J. Gallagher, S. J. Cooke, and N. Hammerschlag. 2018. Integrating reflexes with physiological measures to evaluate coastal shark stress response to capture. ICES J. Mar. Sci. 75:796-804. Crossref

Kajiura, S. M., and S. L. Tellman.

2016. Quantification of massive seasonal aggregations of blacktip sharks (Carcharhinus limbatus) in southeast Florida. PLoS ONE 11(3):e0150911. Crossref

Keltz, E., F. Y. Khan, and G. Mann.

2013. Rhabdomyolysis. The role of diagnostic and prognostic factors. Muscles Ligaments Tendons J. 3:303-312. Crossref

Kerstetter, D. W., J. J. Polovina, and J. E. Graves.

2004. Evidence of shark predation and scavenging on fishes equipped with pop-up satellite archival tags. Fish. Bull. 102:750-756.

Kilfoil, J. P., B. M. Wetherbee, J. K. Carlson, and D. A. Fox.

2017. Targeted catch-and-release of prohibited sharks: sand tigers in coastal Delaware waters. Fisheries 42:281-287. Crossref

Killam, K. A., and G. R. Parsons.

1989. Age and growth of the blacktip shark, Carcharhinus limbatus, near Tampa Bay, Florida. Fish. Bull. 87:845-857.

Kneebone, J., J. Chisholm, D. Bernal, and G. Skomal.

2013. The physiological effects of capture stress, recovery, and post-release survivorship of juvenile sand tigers (Carcharhias taurus) caught on rod and reel. Fish. Res. 147:103-114. Crossref

Korsmeyer, K. E., H. Dewar, N. C. Lai, and J. B. Graham.

1996. The aerobic capacity of tunas: adaptation for multiple metabolic demands. Comp. Biochem. Physiol. A 113:17-24. Crossref

Lawrence, M. J., G. D. Raby, A. K. Teffer, K. M. Jeffries, A. J. Danylchuk, E. J. Eliason, C. T. Hasler, T. D. Clark, and S. J. Cooke.

2020. Best practices for non-lethal blood sampling of fish via the caudal vasculature. J. Fish Biol. 97:4-15. Crossref 
Lear, K. O., and N. M. Whitney.

2016. Bringing data to the surface: utilizing data loggers for large sample sizes from marine vertebrates. Anim. Biotelem. 4:12. Crossref

Manabe, R., J. Aoyama, K. Watanabe, M. Kawai, M. J. Miller, and K. Tsukamoto.

2011. First observations of the oceanic migration of Japanese eel, from pop-up archival transmitting tags. Mar. Ecol. Prog. Ser. 437:229-240. Crossref

Mandelman, J. W., and G. B. Skomal.

2009. Differential sensitivity to capture stress assessed by blood acid-base status in five carcharhinid sharks. J. Comp. Physiol. B 179:267. Crossref

Manire, C., R. Hueter, E. Hull, and R. Spieler.

2001. Serological changes associated with gill-net capture and restraint in three species of sharks. Trans. Am. Fish. Soc. 130:1038-1048. Crossref

Marshall, H., L. Field, A. Afiadata, C. Sepulveda, G. Skomal, and D. Bernal.

2012. Hematological indicators of stress in longlinecaptured sharks. Comp. Biochem. Physiol. A 162:121129. Crossref

Marshall, H., G. Skomal, P. G. Ross, and D. Bernal.

2015. At-vessel and post-release mortality of the dusky (Carcharhinus obscurus) and sandbar (C. plumbeus) sharks after longline capture. Fish. Res. 172:373-384. Crossref

Medbø, J. I., and O. M. Sejersted.

1990. Plasma potassium changes with high intensity exercise. J. Physiol. 421:105-122.

Moyes, C. D., N. Fragoso, M. K. Musyl, and R. W. Brill.

2006. Predicting postrelease survival in large pelagic fish. Trans. Am. Fish. Soc. 135:1389-1397. Crossref

Muoneke, M. I., and W. M. Childress.

1994. Hooking mortality: a review for recreational fisheries. Rev. Fish. Sci. 2:123-156. Crossref

Musick, J. A., S. Branstetter, and J. A. Colvocoresses.

1993. Trends in shark abundance from 1974 to 1991 for the Chesapeake Bight region of the U.S. Mid-Atlantic coast. In Conservation biology of elasmobranchs (S. Branstetter, ed.), 1-19 p. NOAA Tech. Rep. NMFS 115.

Musyl, M. K., and E. L. Gilman.

2018. Post-release fishing mortality of blue (Prionace glauca) and silky shark (Carcharhinus falciformes) from a Palauan-based commercial longline fishery. Rev. Fish Biol. Fish. 28:567-586. Crossref

Musyl, M. K., M. L. Domeier, N. Nasby-Lucas, R. W. Brill,

L. M. McNaughton, J. Y. Swimmer, M. S. Lutcavage, S. G. Wilson,

B. Galuardi, and J. B. Liddle.

2011. Performance of pop-up satellite archival tags. Mar. Ecol. Prog. Ser. 433:1-28. Crossref

Nikinmaa, M.

1992. Membrane transport and control of hemoglobinoxygen affinity in nucleated erythrocytes. Physiol. Rev. 72:301-321. Crossref

NMFS (National Marine Fisheries Service).

2019. 2018 stock assessment and fishery evaluation (SAFE) report for Atlantic highly migratory species, $234 \mathrm{p}$. Highly Migratory Species Manage. Div., Off. Sustainable Fish., Natl. Mar. Fish. Serv., NOAA, Silver Spring, MD. [Available from website.]

Pacheco, J. C., D. W. Kerstetter, F. H. Hazin, H. Hazin, R. S. S. L. Segundo, J. E. Graves, F. Carvalho, and P. E. Travassos.

2011. A comparison of circle hook and $J$ hook performance in a western equatorial Atlantic Ocean pelagic longline fishery. Fish. Res. 107:39-45. Crossref
Press, K. M., J. Mandelman, E. Burgess, S. J. Cooke, V. M. Nguyen, and A. J. Danylchuk.

2016. Catching sharks: recreational saltwater angler behaviours and attitudes regarding shark encounters and conservation. Aquat. Conserv.: Mar. Freshw. Ecosyst. 26:689-702. Crossref

Priede, I. G.

1985. Metabolic scope in fishes. In Fish energetics: new perspectives (P. Tytler and P. Calow, eds.), p. 33-66. Croom Helm, London.

Prince, E. D., M. Ortiz, and A. Venizelos.

2002. A comparison of circle hook and "J" hook performance in recreational catch-and-release fisheries for billfish. Am. Fish. Soc. Symp. 30:66-79.

$\mathrm{R}$ Core Team.

2018. R: a language and environment for statistical computing. R Foundation for Statistical Computing, Vienna, Austria. [Available from website, accessed August 2018.]

Rogers, P. J., I. Knuckey, R. J. Hudson, A. D. Lowther, and L. Guida. 2017. Post-release survival, movement, and habitat use of school shark Galeorhinus galeus in the Great Australian Bight, southern Australia. Fish. Res. 187:188-198. Crossref

Rose, D. A

1996. An overview of world trade in sharks and other cartilaginous fishes, 106 p. TRAFFIC Int., Cambridge, UK.

Schlenker, L. S., R. J. Latour, R. W. Brill, and J. E. Graves.

2016. Physiological stress and post-release mortality of white marlin (Kajikia albida) caught in the United States recreational fishery. Conserv. Physiol. 4:cov066. Crossref

Sejersted, O. M., and G. Sjøgaard.

2000. Dynamics and consequences of potassium shifts in skeletal muscle and heart during exercise. Physiol. Rev. 80:1411-1481. Crossref

Sepulveda, C. A., C. Heberer, S. A. Aalbers, N. Spear, M. Kinney, D. Bernal, and S. Kohin.

2015. Post-release survivorship studies on common thresher sharks (Alopias vulpinus) captured in the southern California recreational fishery. Fish. Res. 161:102-108. Crossref

Sheridan, M. A., and N. A. Muir.

1988. Effects of epinephrine and norepinephrine on glucose release from Chinook salmon (Oncorhynchus tshawytscha) liver incubated in vitro. J. Exp. Zool. 248:155-159. Crossref

Sherwin, R. S., H. Shamoon, R. Hendler, L. Saccà, N. Eigler, and M. Walesky.

1980. Epinephrine and the regulation of glucose metabolism: effect of diabetes and hormonal interactions. Metabolism 29:1146-1154. Crossref

Shiffman, D. S., C. Macdonald, H. Y. Ganz, and N. Hammerschlag. 2017. Fishing practices and representations of shark conservation issues among users of a land-based shark angling online forum. Fish. Res. 196:13-26. Crossref

Skomal, G. B.

2007. Evaluating the physiological and physical consequences of capture on post-release survivorship in large pelagic fishes. Fish. Manage. Ecol. 14:81-89. Crossref

Skomal, G. B., and J. W. Mandelman.

2012. The physiological response to anthropogenic stressors in marine elasmobranch fishes: a review with a focus on the secondary response. Comp. Biochem. Physiol. A 162:146-155. Crossref

Talwar, B., E. J. Brooks, J. W. Mandelman, and R. D. Grubbs.

2017. Stress, post-release mortality, and recovery of commonly discarded deep-sea sharks caught on longlines. Mar. Ecol. Prog. Ser. 582:147-161. Crossref 
Tolentino, E. R., R. P. Howey, L. A. Howey, L. K. B. Jordan, R. D. Grubbs, A. Brooks, S. Williams, E. J. Brooks, and O. N. Shipley. 2017. Was my science project eaten? A novel approach to validate consumption of marine biologging instruments. Anim. Biotelem. 5:3. Crossref

Ulrich, G. F., C. M. Jones, W. B. Driggers III, J. M. Drymon, D. Oakley, and C. Riley.

2007. Habitat utilization, relative abundance, and seasonality of sharks in the estuarine and nearshore waters of South Carolina. Am. Fish. Soc. Symp. 50:125-139.

van Dijk, P. L. M., and C. M. Wood.

1988. The effect of $\beta$-adrenergic blockade on the recovery process after strenuous exercise in the rainbow trout, Salmo gairdneri Richardson. J. Fish Biol. 32:557-570. Crossref

Wegner, N. C., C. A. Sepulveda, K. B. Bull, and J. B. Graham.

2010. Gill morphometrics in relation to gas transfer and ram ventilation in high-energy demand teleosts: scombrids and billfishes. J. Morphol. 271:36-49. Crossref
Whitney, N. M., C. F. White, A. C. Gleiss, G. D. Schwieterman, P. Anderson, R. E. Hueter, and G. B. Skomal.

2016. A novel method for determining post-release mortality, behavior, and recovery period using accelerometer data loggers. Fish. Res. 183:210-221. Crossref

Whitney, N. M., C. F. White, P. A. Anderson, R. E. Hueter, and G. B. Skomal.

2017. The physiological stress response, post-release behavior, and mortality of blacktip sharks (Carcharhinus limbatus) caught on circle and J-hooks in the Florida recreational fishery. Fish. Bull. 115:532-543. Crossref

Wood, C. M.

1991. Acid-base and ion balance, metabolism, and their interactions, after exhaustive exercise in fish. J. Exp. Biol. 160:285-308. 